\title{
Protective Effects of $\omega-3$ PUFA in Anthracycline-Induced Cardiotoxicity: A Critical Review
}

\author{
Simona Serini ${ }^{1, \dagger}{ }^{,}$, Renata Ottes Vasconcelos ${ }^{2,+}$, Renata Nascimento Gomes ${ }^{2}$ \\ and Gabriella Calviello ${ }^{1, *}$ \\ 1 Istituto di Patologia Generale, Università Cattolica del Sacro Cuore, Largo Francesco Vito, 1-00168 Roma, \\ Italy; simona.serini@unicatt.it \\ 2 Center for Translational Research in Oncology (Laboratory of Medical Investigation \#24), \\ Department of Radiology and Oncology, School of Medicine of São Paulo University, \\ Cancer Institute of São Paulo, São Paulo 01246-000, Brazil; renataottes@yahoo.com.br (R.O.V.); \\ renataalex@usp.br (R.N.G.) \\ * Correspondence: gabriella.calviello@unicatt.it; Tel.: +39-6-3015-4914 \\ + These authors contributed equally to this work.
}

Received: 9 November 2017; Accepted: 8 December 2017; Published: 12 December 2017

\begin{abstract}
It has been demonstrated that $\omega-3$ polyunsaturated fatty acids ( $\omega-3$ PUFA) may exert a beneficial role as adjuvants in the prevention and treatment of many disorders, including cardiovascular diseases and cancer. Particularly, several in vitro and in vivo preclinical studies have shown the antitumor activity of $\omega-3$ PUFA in different kinds of cancers, and several human studies have shown that $\omega-3$ PUFA are able to decrease the risk of a series of cardiovascular diseases. Several mechanisms have been proposed to explain their pleiotropic beneficial effects. $\omega-3$ PUFA have also been shown to prevent harmful side-effects (including cardiotoxicity and heart failure) induced by conventional and innovative anti-cancer drugs in both animals and patients. The available literature regarding the possible protective effects of $\omega-3$ PUFA against anthracycline-induced cardiotoxicity, as well as the mechanisms involved, will be critically discussed herein. The study will analyze the critical role of different levels of $\omega-3$ PUFA intake in determining the results of the combinatory studies with anthracyclines. Suggestions for future research will also be considered.
\end{abstract}

Keywords: anthracyclines; cardioprotection; cardiotoxicity; chemotherapy; $\omega-3$ PUFA

\section{Introduction}

$\omega-3$ polyunsaturated fatty acids (PUFA) are dietary factors acknowledged for their ability to induce multiple beneficial effects [1-4]. The protection exerted by these fatty acids has been associated to their ability to prevent pathologies affecting various tissues and organs, by modulating a variety of cellular processes, molecular pathways and factors [5-8]. Initially, the cardiovascular (CV) area was identified as the site where an increased intake of $\omega-3$ could preferentially carry out their beneficial action [3]. Only subsequently was it hypothesized that $\omega-3$ PUFA could also protect against the development and progression of several kinds of cancers. Among the mechanisms proposed for their anticancer activity, some are similar to those involved in their CV protective effects, while others are more specifically involved in cancer cell growth and survival [9-12]. Particular attention has been focused on the possibility that these dietary factors may act as adjuvants of already existing antineoplastic drugs, either by increasing the sensitivity of cancer cells towards these drugs or by reducing their dangerous side-effects [13,14]. In the present review, a brief discussion will be firstly outlined on the possibility to prevent both CV diseases and cancer through an increased intake of 
these fatty acids, and the mechanisms involved. In particular, their combinations with antineoplastic agents will be considered. Moreover, the possibility that $\omega-3$ PUFA may reduce the cardiotoxicity induced by chemotherapy - particularly with anthracyclines (ATC) —will be critically analyzed. This is a topic of great interest, being ATC still largely used in a variety of cancers, mainly in combination with conventional or innovative drugs [15].

\section{2. $\omega-3$ PUFA and Cardiovascular (CV) Diseases}

$\mathrm{CV}$ diseases (CVDs) are chronic non-communicable diseases responsible for the highest morbidity and mortality worldwide and, according to the last report by the World Health Organization, they kill 17.7 million people each year [16]. Currently, diet and lifestyle are considered major risk factors for CVD $[17,18]$. On the other hand, intervention on both factors may help in the prevention of these diseases and their clinical events. In particular, it is acknowledged that dietary $\omega-3$ PUFA are among the nutritional factors which beneficially affect the frequency and severity of CVD $[3,19] . \alpha$-Linolenic acid (ALA 18:3w-3), found in vegetables, is the precursor of the most effective long-chain PUFA (LC-PUFA) eicosapentaenoic acid (EPA 20:5 $\omega$-3) and docosahexaenoic acid (DHA 22:6w-3), present at high levels in marine fatty fish and seafood [20-22]. A great number of studies have directly associated $\omega-3$ dietary consumption to a series of beneficial effects at CV level, such as: prevention of arrhythmias [23], platelet aggregation [24], and arterial inflammatory responses [25]; normalization of plasma triacylglycerol [26] and blood pressure [27]; and improvement of vascular relaxation [27] and heart rate variability $[28,29]$.

The specific mechanisms underlying the cardioprotective effects of $\omega-3$ PUFA are not fully understood. It is believed that the ability of these dietary fatty acids to exert pleiotropic effects in cells and tissues is mainly related to the fact that they are incorporated in structural phospholipids of cellular membranes [30,31], and alter their physicochemical properties, such as permeability, deformability [32,33], and fluidity [3]. Consequently, cellular components and signaling pathways may be affected [34]. For instance, the relative refractory period of myocyte voltage-gated sodium channels may be prolonged, the voltage required for membrane depolarization increased, thus leading to anti-arrhythmic effects [35]. Moreover, the $\omega-3$ modulatory action on L-type calcium channels may result in reduced cytosolic free $\mathrm{Ca}^{2+}$ and $\mathrm{Ca}^{2+}$ influx rate, which is believed to prevent the cytosolic calcium overload taking place during the ischemic insult [36]. The anti-inflammatory and anti-thrombotic effects of $\omega-3$ PUFA have mainly been related to their metabolic conversion to oxygenated derivatives, which are broadly named oxylipins, and are highly bioactive factors acting at very low concentrations [37,38]. Following a stimulus, both the LC- $\omega-3$ PUFA EPA and DHA or the $\omega-6$ PUFA arachidonic acid (AA), are released from cell membranes and converted to oxylipins with similar structures, but often contrasting effects. There are three main pathways for these conversions, mediated by the enzymes cyclooxygenase (COX), lipoxygenase (LOX), and cytochrome P-450 (Cyt P450). As the tissue level of LC- $\omega-3$ PUFA increases, they compete with AA for COX-2 and LOX enzymatic conversions, increasing the production of 3-series prostaglandins (PG), which are vasodilators and platelet aggregation inhibitors [39], and that of thromboxane $A_{3}$ (TXA3) and leukotriene $B_{5}$ (LTB5) which, compared to the analogous AA-derived compounds (PGE2 and LTB4), are weaker platelet aggregators and less strong inducers of inflammation [40]. Lastly, $\omega-3$ PUFA give rise to resolvins, metabolic derivatives with powerful anti-inflammatory and pro-resolving effects [41]. At the CV level, the increased formation of these specific LC- $\omega-3$ PUFA products are thought to reduce atherosclerotic plaque formation and induce their stabilization by decreasing the infiltration of inflammatory and immune cells [42]. The ability of $\omega-3$ PUFA to inhibit the secretion of very low density lipoproteins (VLDL) from liver, as well as the conversions of VLDL to intermediate-density lipoprotein (IDL), and low density lipoproteins (LDL) has been related to their hypotriglyceridemic effect [43]. On the other hand, this effect has also been explained based on the ability of $\omega-3$ fatty acids to increase $\beta$-oxidation, thus leading to the reduction of the fatty acid substrate for triglyceride synthesis [44-46]. 


\section{3. $\omega-3$ PUFA and Cancer}

Several preclinical (in vitro and in vivo) studies and some human experimental studies have demonstrated the ability of $\omega-3$ PUFA to decrease cancer cell proliferation, to promote cancer cell death and to inhibit neoangiogenesis in cancer [47-49]. Interestingly, these anticancer effects are induced by $\omega-3$ PUFA only in cancer cells and not in normal cells [50]. Among the main mechanisms involved in the $\omega-3$ PUFA antineoplastic action, there is the modulation of cell proliferation and survival, that is associated to their ability to affect the expression and/or function of genes, proteins (membrane carriers and receptors, intracellular components of signaling pathways) and lipid mediators (oxylipins) involved in these biological processes. One possibility that these compounds have in obtaining this result is linked to their ability to modify the chemical structure and physical properties of those specialized lipid microenvironments in plasma membranes (lipid rafts) $[6,30,31,51,52]$, where multiple factors involved in signaling are concentrated and interact each other. The alterations induced by $\omega-3$ PUFA in membranes can substantially modulate important signaling pathways for cancer development. As a result, they can reduce the expression/activity of the nuclear transcription factor- $\mathrm{kB}$ (NF- $\mathrm{kB}$ ) in several kinds of cancer cells, thus inducing apoptosis [53-56]. $\omega-3$ PUFA can also inhibit cancer cell growth by altering the levels of several factors involved in the progression of the cell cycle, such as cyclins, cyclin-dependent kinases and retinoblastoma protein [31]. Another mechanism through which $\omega-3$ PUFA are thought to act is due to their chemical structure and susceptibility to peroxidation. It has been suggested that the incorporation of these PUFA in membranes and mitochondrial phospholipids can sensitize tumor cells to oxygen reactive species (ROS) $[57,58]$. Moreover, it is known that lipid peroxidation products may directly inhibit DNA synthesis, cell growth, and induce tumor cell death [59-61].

Furthermore, there is general agreement on the fact that the powerful anticancer effects exerted by $\omega-3$ PUFA may be partly related to their metabolic conversion to oxylipins. These derivatives have been shown to influence key events in processes involved in the development of cancer, such as cell proliferation, survival and inflammation. We have already considered that, overall, some of the oxylipins derived from EPA and DHA metabolism exert less powerful pro-inflammatory actions than the analogous products originating from AA (i.e., PG), and that other LC- $\omega-3$ PUFA specific products (i.e., resolvins) prevent inflammation and induce its resolution [41]. These anti-inflammatory properties are worth underlining, since inflammation has been considered to play a central role in the development of several cancers. Moreover, while AA-derived oxylipins usually promote cancer cell proliferation, those derived from $\omega$-3 exert a clear anti-proliferative role [62]. The formation of AA-derived products is usually controlled, but excessive concentrations are produced in pathological conditions, such as cancer. By competing with AA for both the incorporation in membranes and oxidative metabolism, EPA and DHA have the potential to induce a decrease of the AA-derived products, and, thus, to reduce the molecular responses associated with AA metabolism [31,50].

\section{Potential Adjuvant Role of $\omega-3$ PUFA in Combination with Antineoplastic Drugs}

The combined treatment of $\omega-3$ PUFA with other already used anticancer chemotherapeutics represents the more possible application of these nutrients in cancer therapy [13]. To date, the potential adjuvant role of $\omega-3$ PUFA has been investigated in combination with a series of conventional drugs in a wide range of cancers (for a comprehensive review, see [13]). The ability of these fatty acids to reduce the toxic side-effects of these drugs has been largely proven [63-65], and several results have also concurred to demonstrate their chemosensitizing effects, as well as their ability to prevent drug-resistance [66-68]. In a recent review that comprehensively analyzed all the results of the existing combinatory studies, we concluded that most of them supported a potential adjuvant-role for $\omega-3$ PUFA [13]. The findings achieved in the two last years have further substantiated the results analyzed in our review. The new information was obtained either by using different cancer cell models, or by studying new molecular and cellular mechanisms for the previously investigated combinations, such as DHA combined with 5-fluorouracyl [69], or cisplatin [70], or docetaxel [71]. Overall, the suppression 
of cell survival pathways and induction of cell death are among the most important mechanisms to explain the chemosensitizing effects of these fatty acids in a variety of cancers [13]. The suppression of cancer cell stemness has also been recently reported [68], and multiple results have suggested that oxidative stress-induced cytotoxicity plays a central role $[13,48,68]$, particularly if the drugs used in combination with $\omega-3$ PUFA were themselves inducers of oxidative stress (such as ATC, or disulfiram) [68].

Some recent papers have also investigated the ability of $\omega-3$ to sensitize cells to the action of new-generation single-targeted drugs. For instance, the combined treatment with LC- $\omega-3$ PUFA and bortezomib synergistically induced apoptosis and increased the sensitivity of human myeloma cells to this drug [72]. DHA combined with trastuzumab, a specific inhibitor of the HER2 receptor, increased the efficacy of this drug in inhibiting the growth of Her2/neu positive breast cancer cells, by synergistically reducing the expression of the phosphorylated form of extracellular signal-regulated kinase (p-) and protein kinase B (p-AKT) [73]. Moreover, the combined treatment of DHA with everolimus or barasertib synergistically promoted ROS-dependent cytotoxicity in Jurkat acute lymphoblastic leukemia cells [65].

Human studies investigating the activity of $\omega-3$ PUFA, such as chemosensitizers or suppressors of drug-resistance, are still scarce. In a phase II trial, Bougnoux et al. [74] reported that treatment with DHA, in combination with ATC-based chemotherapy, could improve the time to progression and overall survival in metastatic breast cancer patients, in particular of those able to incorporate high levels of DHA in plasma phospholipids. Accordingly, in patients with advanced non-small cell lung cancer [75], the addition of fish oil (FO) to standard chemotherapy with carboplatin/vinorelbine or carboplatin/gemcitabine proved to have the potential to enhance the efficacy of these treatments (increase in one-year survival index, response rate and clinical benefit). On the contrary, many human studies have reported that $\omega-3$ PUFA may reduce some of the chemotherapy-induced harmful side-effects, including drug-induced cardiotoxicity (specifically ATC-induced, see Section 5), thus improving chemotherapy tolerance and prognosis [13,76,77].

\section{Can Anthracyclines (ATC)-Induced Cardiotoxicity Be Prevented by w-3 PUFA?}

Almost all the results related to the potential of $\omega-3$ PUFA in preventing cardiac events induced by chemotherapy refer to the treatments with the ATC antibiotics [78-83]. The possibility to prevent ATC-induced cardiotoxicity is a field of great interest, since this class of drugs is still the most extensively used in a variety of human solid and hematological cancers (e.g., breast cancer, sarcoma, lymphoma and pediatric leukemia) in combination with other categories of conventional chemotherapeutic agents or new-generation targeted drugs [15]. From a chemical point of view, these drugs are planar molecules consisting of a rigid hydrophobic tetracycline ring to which a daunosamine sugar is attached through a glycosidic bond. These compounds were introduced as chemiotherapic drugs for the first time in the 1960s [84]. Doxorubicin (DOX) and daunorubicin (DNR) are the two naturally occurring anthracyclines, derived from the bacterium Streptomyces peucetius [85]. Due to their high efficacy, a great number of synthetic analogs have been synthetized [86]. Among these, epirubicin (EPI), which is widely used for the treatment of both carcinomas and sarcomas [87], is synthesized through an epimerization reaction of one hydroxyl group of DOX. One important characteristic of EPI is that, even showing a very similar antitumor activity compared to DOX, it is more glucuronitated and, therefore, better excreted through bile and urine, allowing a safe use at higher doses with respect to DOX [88]. The use of these drugs may often induce acquired resistance [89] and a series of harmful side effects, including mucositis, nausea, vomiting, stomatitis and, mainly, high cardiotoxicity.

To identify the mechanisms of ATC-induced cardiotoxicity, a variety of cellular and molecular pathways have been explored over the last three decades. The precise knowledge of these mechanisms represents an essential prerequisite to identify possible strategies and treatments to inhibit the development of cardiotoxicity. However, despite the great effort, there is still a lack of agreement 
on which alteration(s) may be the most directly responsible for ATC-induced cardiotoxicity [15]. Given the complexity of this topic, it is not possible to analyze in detail herein all the mechanisms involved in ATC-induced cardiotoxicity. Recently, excellent reviews [15,90] have been published on this topic, and we will hereinafter provide only a brief outline of the mechanisms so far identified (next paragraph). $\omega$-3 PUFA appear as ideal candidates in preventing the development of cardiac events induced by ATC chemotherapy, since these fatty acids are known to induce benefits at a cardiovascular level by positively modulating some of the cellular processes and molecular pathways that, conversely, are harmfully altered by ATC and other chemotherapeutic agents.

\subsection{Mechanisms of ATC-Induced Toxicity}

ATC induce cardiotoxicity with acute, sub-acute or chronic clinical manifestations, and the incidence of chronic cardiac pathologies (mainly cardiomyopathy and congestive heart failure) has been directly related to the amount of drugs accumulated in the heart [91]. Conventionally, the main pathogenic role has been attributed to the oxidative stress generated by an increased production of intracellular ROS, that has been thought to be initiated by the redox cycling of ATC and amplified by the formation of free radicals catalyzed by iron chelated by ATC and, subsequently, accumulated in the heart [91,92]. Moreover, the moderately scarce antioxidant defenses of the myocardium have also been thought to be per se a sufficient reason in explaining the high susceptibility of this tissue to ATC-induced-cytotoxicity [15]. In addition, ATC, and DOX in particular, mainly accumulate in the mitochondria, which are mostly concentrated in the myocardium $[93,94]$. However, the oxidative stress hypothesis has been challenged by the outcomes of clinical studies showing that antioxidants failed to provide protection against ATC-induced cardiotoxicity $[95,96]$. Nevertheless, other mechanisms have also been hypothesized. For instance, it has been suggested that cardiotoxicity may also be related to oxidative-independent myocardial cell damage and death associated to the overload of iron in the free form, since DOX can target proteins that specifically bind, transport or regulate the binding and transport of iron [91]. In line with this, it has been shown that the supplementation of rats in vivo with iron produced cardiac free iron accumulation and intensified the cardiotoxic effects of these drugs [97]. On the contrary, iron chelation can prevent ATC-induced cardiotoxicity. Similarly, the iron chelator dexrazoxane has been used to prevent heart pathologies secondary to chemotherapy, not without controversies due to its toxicity and possible carcinogenicity [15]. Other iron chelators have failed to demonstrate the same effectiveness $[98,99]$. This may be because dexrazoxane has shown to possess additional effects, being able to also inhibit topoisomerase $2 \beta$ (Top2 $\beta$ ) [100], an enzyme that traps DNA and DOX to form a DNA cleavage complex which is able to trigger apoptosis [101]. Several alternative oxidative (i.e., alteration of activity of endothelial nitric oxide synthase (eNOS) and nicotinamide adenine dinucleotide phosphate (NADPH) oxidase) and non-oxidative molecular pathways of ATC-cardiotoxicity have also been suggested, although their detailed description is far beyond the scope of this review [15]. However, it is worth mentioning some mechanisms recently proposed, since $\omega-3$ PUFA can often affect them in an opposite way compared to ATC. Particularly relevant in this context is the inflammatory hypothesis, which considers the activation of the innate immunity and the release of inflammatory cytokines central in the development and progression of the ATC-induced cardiotoxicity [102-104]. Similarly, it is worth pointing out the modulatory activity of ATC on the expression of several miRNA involved in the epigenetic regulation of different pathways of apoptosis, since $\omega-3$ fatty acids have also been shown to modulate the epigenetic regulation of gene expression $[7,105,106]$.

Furthermore, it is worth noting the emerging hypothesis [90] suggesting a central role for the ATC-induced dysregulation of the autophagic response, since the ability of $\omega-3$ PUFA in regulating the autophagic processes has also been reported [107]. An impaired autophagic process results in an unbalanced cellular proteostasis with an excessive protein load that may ultimately induce cell death. However, although multiple results have shown that DOX deeply affects the autophagic process in the heart, and that, by reversing the DOX effects on autophagy, the cardiac cell damage and death 
are also reduced, there is still great uncertainty as to whether the DOX-mediated cardiotoxicity may be related to an increase or a decrease in autophagy $[90,108,109]$. According to the recent analysis of the literature by Bartlett et al. [90], the controversies in this field may be related to the targets examined in the autophagic machinery, and more attention should be focused on the explanation of the "autophagic flux". An impaired autophagic flux, i.e., a decreased lysosomal degradation of autophagosomes $[109,110]$, could be central in DOX-related cardiotoxicity, and its restoration could reduce the heart damage related to the use of this drug.

Lastly, an important aspect of this subject, recently highlighted by Cappetta et al. [111] is that cardiomyocytes have extensively been considered the main cellular targets of ATC chemotherapy, and cardiomyopathy following the therapy has exclusively been ascribed to their death. However, the vulnerability of other cell types (i.e., cardiac cells: cardiac progenitor cells, cardiac fibroblasts, vascular cells; non cardiac cells, such as bone marrow cells and endothelial progenitor cells) to DOX has also been recently described, and involved in the DOX-mediated cardiotoxicity [111]. Thus, these cell types should also be taken into account for further research on ATC-induced cardiotoxicity.

\subsection{Available Evidence for $\omega-3$ Prevention of ATC-Mediated Cardiotoxicity}

Only a small number of preclinical studies have hitherto investigated the effect of $\omega-3$ PUFA on the ATC-induced cardiotoxicity, and their results are quite inconsistent. Among the in vivo animal studies analyzed (Table 1), only two $[112,113]$ reported functional alterations in the hearts from animals orally supplemented with $\omega-3$ PUFA and subject to DOX treatments. On the other hand, two studies [114,115] did not find any effect on cardiac morphology/functions, one [81] reported mixed effects (i.e., both no effects on some parameters and positive effects on others), and the remaining studies supported potential preventive effects of these fatty acids $[78,79,116,117]$. Moreover, one in vivo study [118] (Table 1) did not investigate the functional/morphological effect on the heart, but reported the preventive effects that these fatty acids induced at biochemical and molecular levels in this area. Such beneficial effects were also reported by all the four in vitro studies $[80,82,83,119]$ (Table 2 ) conducted in cardiomyocytes treated with $\omega-3$ PUFA and DOX.

The great variability in the experimental conditions used in the animal studies may explain the inconsistency of their outcomes. For instance, various cumulative doses and ways of administration of ATC have been used which can result in different concentrations of this drug at the cardiac level. Generally, these drugs are administered to humans through intravenous (IV) injections via a central line or a peripheral venous line. In three of the works analyzed, ATC were administered intravenously [81], or "intracoronary" [113,120], whereas most of the studies were performed by injecting the drug intraperitoneally (IP) $[78,79,114,117]$, and the remaining reports did not specify the route of administration. The intracoronary DOX administration was performed in an ovine model, where these vessels are large and easily reached. Possibly, this way of inoculation was used to stress the experimental conditions, in order to obtain higher cardiac DOX concentrations and, consequently, better detect alterations in the heart morphology and functions. Interestingly, one of these studies (Table 1), performed in the ovine model [113], reported a negative effect (in terms of dilation of the left ventricle and greater decline in ejection fraction) of an oral supplementation (19 weeks) with $23 \mathrm{~mL}$ of Omega 18/12 fish oil (FO) (Melrose Health, Mitcham, Victoria, Australia, containing 30\% $\mathrm{EPA}+\mathrm{DHA}$ ) given before, simultaneously, and after the DOX treatment (cumulative DOX dose: 3-4 mg/kg body weight). However, the same group of authors [120] had previously used the same ovine model, and had found protective effects at the atrial level (suppression of left atrial dilation and interstitial fibrosis, as well as decreased alteration in atrial conduction) (Table 1). In this case, the sheep were supplemented daily with $10 \mathrm{~mL}$ of the same FO, and injected with comparable amounts of DOX (cumulative DOX dose: $3.6 \mathrm{mg} / \mathrm{kg}$ body weight). Thus, it is not clear if the contrasting effects between the two works could be ascribed to the different cardiac regions and parameters examined or to the different supplementation timing of a quantitatively comparable $(3 \mathrm{~g} /$ day $)$ $\mathrm{EPA}+\mathrm{DHA}$ supplementation. The only other work reporting negative health effects from $\omega-3$ 
PUFA (increased mortality and worst cardiac performance, i.e., reduction of left ventricular fractional shortening, LVFS) was conducted by Matsui et al. [112] in rats (Table 1). In this case, the animals were dietary supplemented with $10 \%$ menhaden oil (MO, Sigma, St. Louis, MO, USA, containing approximately 20-30\% EPA + DHA, for seven weeks in total). This supplementation provided the rats with approximately 2.0-3.0 g EPA + DHA $/ \mathrm{kg}$ body weight/day (see [121] for calculations). The animals received three weeks of MO treatment, and were then injected with DOX (cumulative dose: $15 \mathrm{mg} / \mathrm{kg}$ body weight, injection and timing not specified). On the contrary, in the two studies conducted by Germain et al. [114,115], where $\omega-3$ supplementations were found neutral for heart health, rats were treated daily with epirubicin (EPI, cumulative dose: 9-15 mg/kg), and their diet was enriched with $15 \%$ sardine oil (SO, Polaris Biotechnique, Columbus, $\mathrm{OH}$, USA, containing about $30 \%$ $\mathrm{EPA}+\mathrm{DHA}$, and corresponding to a dose of about $4.5 \mathrm{~g}$ EPA + DHA $/ \mathrm{kg}$ body weight) or with $15 \%$ algal-derived triglyceride DHASCO oil (containing about $40 \%$ DHA and corresponding to a dose of about $6.0 \mathrm{~g}$ DHA/ kg body weight) [115] (Table 1). These authors also added anti-or pro-oxidants to the diets, but never found changes at the cardiac levels, either at the lowest dose or the highest dose of $\omega-3$ [115]. It should be emphasized that, compared to the work by Matsui et al. [112], in which $\omega-3$ induced harmful cardiac effects in rats treated with DOX, in the studies by Germain et al. [114,115], higher doses of EPA + DHA were administered to the rats (4.5-6 g/ $\mathrm{kg}$ body weight vs. $2-3 \mathrm{~g} / \mathrm{kg}$ body weight). This is quite unusual, since, if $\omega-3$ had the potential to increase the ATC-induced cardiotoxicity, we would expect to observe greater alterations at the cardiac level by treating the animals with higher doses of these fatty acids. However, it should be underlined that Germain et al. [114] did not use DOX, but EPI, which, at comparable cumulative doses, is less cardiotoxic than DOX [122]. It is also interesting to notice that the neutral effects obtained by Germain et al. $[114,115]$ were interpreted by the authors as a favorable result, since their studies were aimed at assessing whether $\omega-3$ PUFA would exacerbate the CV effect induced by these drugs, in addition to chemo-sensitizing breast cancer to ATC therapy.

The beneficial effects on functional parameters at the cardiac level observed by Teng et al. [78] (Table 1) were obtained by supplementing rats with $6 \mathrm{~g} \mathrm{FO} / \mathrm{kg}$ body weight by gastric gavage. The type of FO was not specified, but, if it had a EPA + DHA content of approximately 20-30\%, as it is generally observed in the FO mostly used in animal studies (menhaden oil or MaxEPA, see [121]), the rats would have received a daily dose of about $1.5 \mathrm{~g}$ EPA + DHA, that is about a half of that ingested by the rats showing cardiotoxic effects in the work by Matsui et al. [112]. Moreover, it should be pointed out that these authors [112] supplemented $\omega$-3 PUFA incorporated in the diet and not, as in this work, by gastric gavage [78] that, presumably, allows a more precise intake and a higher bioavailability of these fatty acids in the serum and tissues. Perhaps, also the longer period of $\omega-3$ supplementation (eight weeks vs. four weeks) used in this case [78] allowed to obtain healthy cardiac effects, although this treatment was performed after the DOX treatment (IP injection) and not before it, as in the study by in Matsui et al. [112] (where the type of DOX injection was not specified). More recently, Uygur et al. [79] (Table 1) also obtained protective effects at the cardiac levels (in terms of improved cardiac histological parameters and reduced apoptotic index) by administering the rats by gavage $0.4 \mathrm{~g} / \mathrm{kg}$ body weight of EFA capsules (New Life EFA S-1200, Eurocaps Limited, Dukestown, Tredegar, UK, containing $60 \% \mathrm{EPA}+\mathrm{DHA})$, corresponding to a dose of $\omega-3(0.240 \mathrm{~g} / \mathrm{kg}$ body weight $)$ even lower than that of Teng et al. [78]. Similar to the study by Matsui et al. [112], in this case, this very low dose was given for four weeks before the treatment with DOX, that, however, was administered at a cumulative dose twice what Matsui et al. [112] had administered the animals ( $30 \mathrm{mg} / \mathrm{kg}$ vs. $15 \mathrm{mg} / \mathrm{kg}$ ). Overall, the works analyzed to date suggest that, providing $\omega-3$ at relatively lower doses (lower than about $2.0 \mathrm{~g} / \mathrm{kg}$ body weight in rats) in the presence of ATC treatments, may induce more favorable cardiac effects. Moreover, they suggest that, even extremely low doses of $\omega-3$ may be efficient, provided that the treatment is performed before ATC, even if the drug is administered at high cumulative doses. 
Table 1. Effect of in vivo $\omega-3$ PUFA treatments on ATC-induced cardiotoxicity in animal models.

\begin{tabular}{|c|c|c|c|c|c|c|c|}
\hline Experimental Model & ATC Treatment & $\omega-3$ PUFA Treatment & $\begin{array}{c}\text { Treatment } \\
\text { Combined with } \\
\omega-3 \text { PUFA }\end{array}$ & $\begin{array}{c}\text { Control Condition } \\
\text { (Alternative to } \omega-3 \text { PUFA } \\
\text { or/and ATC Treatments) }\end{array}$ & $\begin{array}{c}\omega-3 \text { PUFA-Induced } \\
\text { Morphological/Functional Effects at } \\
\text { CV Level }\end{array}$ & $\begin{array}{l}\omega-3 \text { PUFA-Induced } \\
\text { Biochemical and } \\
\text { Molecular Effects }\end{array}$ & Ref. \\
\hline $\begin{array}{l}\text { Rats bearing } \\
\text { NMNU-induced } \\
\text { mammary tumors }\end{array}$ & $\begin{array}{l}\text { EPI (3 mg } / \mathrm{kg} / \text { week; IP) for } \\
\text { 3 weeks }\end{array}$ & Diet containing 15\% SO (6 weeks) & $\begin{array}{c} \pm \text { LP inducers * in } \\
\text { drinking water or } \\
\pm \text { vitamin } E \\
(100 \mathrm{IU} / \mathrm{kg} \text { diet }) \\
\end{array}$ & none & $\begin{array}{c}\text { NO EFFECTS } \\
\mathrm{SO} \pm \mathrm{LP} \text { inducers * or SO } \pm \text { vit E: no } \\
\text { variation in EPI-induced increase in } \\
\text { LVEDP in almost } 10 \% \text { of rats in all groups }\end{array}$ & n.d. & [114] \\
\hline $\begin{array}{l}\text { Hearts isolated from rats } \\
\text { supplemented with } \omega-3 \\
\text { PUFA and perfused ex vivo } \\
\text { with EPI }\end{array}$ & $\begin{array}{l}\text { EPI heart perfusion ex vivo: } \\
0.2 \mathrm{mg} / \mathrm{min} / 10 \mathrm{~min}\end{array}$ & $\begin{array}{c}1.0 \mathrm{~mL}(300 \mathrm{mg}) \text { EPA or DHA } \\
\text { ethylesters suspended in } 0.5 \% \\
\text { carboxymethylcellulose by gavage } \\
\text { (1st week); } 1.5 \mathrm{~mL}(450 \mathrm{mg}) \\
\text { (2nd week) }\end{array}$ & none & $\begin{array}{l}1.0 \mathrm{~mL} \text { (1st week) or } 1.5 \mathrm{~mL} \\
\text { (2nd week) olive oil } \\
\text { (alternative to EPA or } \\
\text { DHA treatments) }\end{array}$ & $\begin{array}{c}\text { PROTECTIVE EFFECTS } \\
\text { Heart from EPA- or DHA-treated rats } \\
\text { perfused with EPI: lower aortic pressure } \\
\text { (index of coronary resistance) than in olive } \\
\text { oil-treated hearts }\end{array}$ & $\begin{array}{l}\text { No difference in the heart } \\
\text { release of LDH among groups } \\
\text { during and after EPI infusion }\end{array}$ & [116] \\
\hline Sprague-Dawley rats & $\begin{array}{l}\text { DOX (cumulative dose): } \\
15 \mathrm{mg} / \mathrm{kg} \text { after } 4 \text { weeks of } \\
\text { FO treatments }\end{array}$ & $\begin{array}{l}\text { Diet containing } 10 \% \text { MO ( } 4 \text { weeks } \\
\text { prior and } 3 \text { weeks } \\
\text { after DOX treatment) }\end{array}$ & none & $\begin{array}{l}0.28 \mathrm{M} \text { dextrose solution } \\
\text { (alternative } \\
\text { to DOX treatment) }\end{array}$ & $\begin{array}{c}\text { HARMFUL EFFECTS } \\
\text { FO diet: } \\
\text {-highest mortality; } \\
\text {-further reduction in cardiac LVFS } \\
\end{array}$ & $\begin{array}{l}\text { FO diet: increase in myocardial } \\
\text { LP and decrease in vit } \mathrm{E} \text { level }\end{array}$ & [112] \\
\hline Sprague-Dawley rats & $\begin{array}{l}\text { After oil treatments: EPI } \\
\text { (weekly, cumulative doses): } \\
9 \mathrm{mg} / \mathrm{kg} \text { (exp. } 1) \\
15 \mathrm{mg} / \mathrm{kg} \text { (exp. } 2 \text { ) }\end{array}$ & $\begin{array}{l}\text { Diet containing } 15 \% \mathrm{SO} \text { or } \\
\text { DHASCO oil (\% not reported) } \\
\text { (at least } 3 \text { weeks before } \\
\text { EPI treatment) }\end{array}$ & $\begin{array}{l} \pm \mathrm{LP} \text { inducers in } \\
\text { drinking water or } \\
\text { vitamin E } \\
(100 \mathrm{IU} / \mathrm{kg} \text { diet })\end{array}$ & $\begin{array}{l}\text { Palm oil (alternative to } \\
\text { DHASCO oil treatment) }\end{array}$ & $\begin{array}{c}\text { NO EFFECTS } \\
\text { SO or DHASCO oils ( } \pm \text { anti- or } \\
\text { pro-oxidants): no changes in EPI-induced: } \\
\text {-mortality; } \\
\text {-alterations of LVEDP and LVSP and left } \\
\text { ventricular systolic pressure; } \\
\text {-histological damages }\end{array}$ & n.d. & [115] \\
\hline Male Sprague-Dawley rats & $\begin{array}{c}\text { IP DOX injection } \\
\text { (2 } \mathrm{mg} / \mathrm{kg} / \text { week) (8 weeks) }\end{array}$ & $\begin{array}{l}\mathrm{FO} \&(0.6 \% \text { of body weight) daily, } \\
\text { by gavage (for } 8 \text { weeks, } \\
\text { after DOX treatment) }\end{array}$ & none & $\begin{array}{l}0.9 \% \text { normal saline } \\
\text { (alternative to FO) }\end{array}$ & $\begin{array}{l}\text { PROTECTIVE EFFECTS } \\
\text { FO supplementation: } \\
\text {-Lower LVEDD and LVESD } \\
\text {-Higher LVEF and LVFS }\end{array}$ & n.d. & [78] \\
\hline Merino wether sheep & $\begin{array}{c}\text { Intracoronary DOX infusions } \\
(1.0 \mathrm{mg} / \mathrm{kg} \text {, every other week) } \\
\text { (for 3-4 weeks) }\end{array}$ & $\begin{array}{l}\text { Oral supplementation: } 1.8 \mathrm{~g} \text { EPA }+ \\
1.2 \mathrm{~g} \text { DHA/day }{ }^{\circ}(1 \text { week prior and } \\
13-15 \text { weeks after the } \\
\text { last DOX infusion })\end{array}$ & none & $\begin{array}{l}\text { No supplementations, sham } \\
\text { operated; } \\
\text { (Alternative to } \omega-3 \\
\text { and DOX treatments) } \\
\text { Olive oil (10 mL) } \\
\end{array}$ & $\begin{array}{c}\text { PROTECTIVE EFFECTS } \\
\text { EPA + DHA supplementation, suppression } \\
\text { of DOX-induced: } \\
\text {-left atrial dilation and interstitial fibrosis; } \\
\text {-alterations in atrial conduction }\end{array}$ & n.d. & [120] \\
\hline Merino wether sheep & $\begin{array}{l}\text { Intracoronary DOX infusion } \\
(1.2 \mathrm{mg} / \mathrm{kg} \text {, every other week) } \\
\text { (for } 3 \text { weeks) }\end{array}$ & $\begin{array}{l}\text { Oral supplementation: } \omega 18 / 12 \mathrm{FO} \\
(23 \mathrm{~mL})(3 \text { times / week for } 3 \text { weeks } \\
\text { prior and } 16 \text { weeks during and } \\
\text { post DOX treatment }\end{array}$ & none & $\begin{array}{l}\text { Oral supplementation with } \\
23 \mathrm{~mL} \text { olive oil (alternative } \\
\text { to FO) }\end{array}$ & $\begin{array}{c}\text { HARMFUL EFFECTS } \\
\text { FO supplementation: left ventricular } \\
\text { dilatation; greater decline in } \\
\text { ejection fraction } \\
\end{array}$ & $\begin{array}{l}\text { More frequent elevation of } \\
\text { serum troponin-T } \\
\text { after DOX treatment in } \omega-3 \\
\text { treated sheep }\end{array}$ & [113] \\
\hline $\begin{array}{c}\text { Female } \\
\text { Sprague-Dawley rats }\end{array}$ & $\begin{array}{l}\text { IV EPI injection ( } 0.8 \mathrm{mg} / \mathrm{kg} \\
\text { once a week) (for } 6 \text { weeks) }\end{array}$ & $\begin{array}{l}\text { Oral supplementation DHASCO oil } \\
80 \mathrm{~g} / \mathrm{kg} \text { diet }(45 \% \text { DHA) for } \\
12-13 \text { weeks prior and } 6 \text { weeks } \\
\text { during EPI treatment }\end{array}$ & none & Palm oil-based diet & n.d. & $\begin{array}{l}\text { In cardiac tissue: no changes in } \\
\text { LP and total antioxidant } \\
\text { activity; increased antioxidant } \\
\text { enzyme (GPx, SOD) activity }\end{array}$ & [118] \\
\hline
\end{tabular}


Table 1. Cont.

\begin{tabular}{|c|c|c|c|c|c|c|c|}
\hline Experimental Model & ATC Treatment & $\omega-3$ PUFA Treatment & $\begin{array}{c}\text { Treatment } \\
\text { Combined with } \\
\omega-3 \text { PUFA }\end{array}$ & $\begin{array}{c}\text { Control Condition } \\
\text { (Alternative to } \omega-3 \text { PUFA } \\
\text { or/and ATC Treatments) }\end{array}$ & $\begin{array}{c}\omega-3 \text { PUFA-Induced } \\
\text { Morphological/Functional Effects at } \\
\text { CV Level }\end{array}$ & $\begin{array}{l}\omega-3 \text { PUFA-Induced } \\
\text { Biochemical and } \\
\text { Molecular Effects }\end{array}$ & Ref. \\
\hline Male Sprague-Dawley rats & $\begin{array}{l}\mathrm{DOX}(2.5 \mathrm{mg} / \mathrm{kg} \text {, IP) (from } \\
\text { the 4th day, every other day) } \\
\text { (for } 7 \text { times) }\end{array}$ & $\begin{array}{l}\text { Pretreatment with ALA ( } 500 \mu \mathrm{\mu g} / \mathrm{kg} \\
\text { body weight) by gavage ( } 3 \text { days); } \\
\text { from the 4th day: every other day } \\
\text { (for } 7 \text { days) }\end{array}$ & none & $\begin{array}{c}\text { Oral supplementation with } \\
\text { normal saline throughout } \\
\text { the experiments (alternative } \\
\text { to ALA } \\
\text { and DOX treatments) }\end{array}$ & $\begin{array}{c}\text { PROTECTIVE EFFECTS } \\
\text { ALA supplementation, suppression } \\
\text { of DOX-induced: } \\
\text {-cardiac histopathological alterations, } \\
\text {-reduction of LVEDV, SV, and EF, } \\
\text {-increase in HW/BW, } \\
\text {-cardiomyocyte apoptosis }\end{array}$ & $\begin{array}{l}\text { ALA prevented DOX-induced: } \\
\text {-in serum: increase in BNP, } \\
\text { CK-MB, LDH, cTII levels; } \\
\text {-in cardiac tissue: LP increase } \\
\text { and antioxidant enzymes ** } \\
\text { decrease; } \\
\text {-caspase-3 activation and } \\
\text { changed BAX and BCL2 } \\
\text { expression; } \\
\text {-p-AKT and p-ERK decreased } \\
\text { expression }\end{array}$ & [117] \\
\hline Sprague-Dawley rats & $\begin{array}{l}\text { Single IP DOX dose } \\
\text { (30 mg/kg, after } 30 \text { day } \omega-3 \\
\text { PUFA treatment) }\end{array}$ & $\begin{array}{l}\text { Pretreatment with } \omega-3 \text { PUFA } \\
\text { capsules (New Life EFA S-1200 } \\
(400 \mathrm{mg} / \mathrm{kg} / \mathrm{d} \text {, by gavage) }(30 \text { days } \\
\text { before DOX injections) }\end{array}$ & none & $\begin{array}{l}0.4 \mathrm{~mL} / \mathrm{kg} \text { saline by gavage } \\
\text { (alternative to } \omega-3 \text { PUFA } \\
\text { and DOX treatments) }\end{array}$ & $\begin{array}{c}\text { PROTECTIVE EFFECTS } \\
\text { PUFA treatment: } \\
\text {-improved cardiac histological appearance; } \\
\text {-reduction of appototic index } \\
\text { (Tunel-positive cardiomyocytes) } \\
\end{array}$ & $\begin{array}{l}\text { Decrease in MDA levels; } \\
\text { increase in SOD and GPx } \\
\text { activities }\end{array}$ & [79] \\
\hline $\begin{array}{c}\text { Female Fisher } 344 \text { rats } \\
\text { bearing syngeneic MatBIII } \\
\text { mammary adenocarcinoma } \\
\text { xenograft }\end{array}$ & $\begin{array}{c}\mathrm{DOX}(1 \mathrm{mg} / \mathrm{kg}, \mathrm{IV}) \text { starting } \\
\text { as tumor mass }=1.2 \mathrm{~cm}^{3} \text { (for } \\
6 \text { days and then weekly for } \\
6 \text { weeks) }\end{array}$ & $\begin{array}{c}\text { Parenteral solution (tail vein) } \\
\text { containing } 0.19 \mathrm{~g} / \mathrm{kg} \text { EPA }+ \\
0.18 \mathrm{~g} / \mathrm{kg} \text { DHA every other day } \\
\text { (6 days before DOX treatment until } \\
\text { day } 50)\end{array}$ & $\begin{array}{l} \pm \text { Parenteral } \\
\text { solution } \\
\text { containing } \\
\text { glutamine } \\
(0.35 \mathrm{~g} / \mathrm{kg}) \pm \mathrm{EPA} \\
+\mathrm{DHA}\end{array}$ & $\begin{array}{l}\text { Parenteral saline } \\
\text { (alternative to } \omega-3 \\
\text { PUFA, DOX) }\end{array}$ & $\begin{array}{c}\text { MIXED EFFECTS } \\
\text { EPA + DHA solution: } \\
\text {-No modifications in DOX-induced: } \\
\text { increase in LVEDD, LVESD and apoptosis; } \\
\text {-Partially improved LV dilation and } \\
\text { function (no statistical significance); } \\
\text {-Reversion of glutamine positive } \\
\text { cardiovascular effects } \\
\end{array}$ & $\begin{array}{l}\text { EPA + DHA parenteral solution } \\
\text { prevents DOX-induced } \\
\text { elevation of plasma cTnI levels; } \\
\text { No effect on DOX-induced lipid } \\
\text { peroxidation and enzymatic } \\
\text { and non-enzymatic } \\
\text { antioxidants in cardiac tissue }\end{array}$ & [81] \\
\hline
\end{tabular}

AKT, protein kinase B; ATC, Anthracyclines; BAX, bcl-2-like protein 4, BCL-2, B-cell lymphoma 2; BNP, brain natriuretic peptide; CAT, catalase; CK-MB, creatine kinase-MB; cTnI, cardiac troponin I; CV, cardiovascular; DHASCO oil, algal-derived triglyceride containing 40\% DHA; DOX, Doxorubicin; EF, ejection fraction; EPI, Epirubicin; ERK, extracellular signal-regulated kinase; FO: Fish oil; GPx, Glutathione peroxidase; HW /BW, heart weight/body weight; IP: Intraperitoneal; IV, Intravenous; LP, lipid peroxidation; LDH, lactate dehydrogenase; LVEDD, left ventricular end-diastolic dimension; LVEDP: left ventricular end diastolic pressure; LVEF: left ventricular ejection fraction; LVESD, left ventricular end-systolic dimension; LVFS: left ventricular fractional shortening: LVSP, left ventricular systolic pressure; MDA, malondialdehyde; MO: menhaden oil; NMNU: $N$-methyl nitrosourea; n.d.: not determined; SO: sardine oil; SOD, Superoxide dismutase; SV: stroke volume; vit. E, vitamin E. *: LP inducers: $20 \mathrm{mg} /$ day dehydroascorbate + $0.2 \mathrm{mg} /$ day menadione. $\$$ : FO, Fish oil not specified; **: SOD, GPx and $\mathrm{CAT}^{\circ}{ }^{\circ}$ equivalent to a daily intake of $10 \mathrm{~mL}$ FO, i.e., $3 \mathrm{~g}$ long-chain $\omega$-PUFA. 
Table 2. Effect of $\omega-3$ PUFA treatments on ATC-induced alterations in cardiomyocytes in vitro.

\begin{tabular}{|c|c|c|c|c|c|c|c|}
\hline Experimental Model & ATC Treatment & $\omega-3$ PUFA Treatment & $\begin{array}{l}\text { Additional } \\
\text { Treatments }\end{array}$ & Control Condition & $\begin{array}{c}\omega-3 \text { PUFA Effect } \\
\text { on DOX-Induced Cardiac } \\
\text { Cell Viability }\end{array}$ & $\begin{array}{c}\text { Effects of } \omega-3 \text { PUFA in } \\
\text { Combination with DOX at } \\
\text { Biochemical and Molecular Levels }\end{array}$ & Ref. \\
\hline $\begin{array}{c}\text { Isolated adult rat } \\
\text { cardiomyocytes } \\
\text { perfused with } \mathrm{CaCl} 2 \\
\text { Krebs solution } \\
\end{array}$ & $\begin{array}{l}100 \mu \mathrm{M} \text { DOX (after } 20 \mathrm{~min} \\
\text { DHA treatment) }\end{array}$ & $\begin{array}{l}\text { Pre-treatment with } 10 \mu \mathrm{M} \\
\text { DHA }(20 \mathrm{~min})\end{array}$ & none & $\begin{array}{l}\text { No treatment with DHA } \\
\pm \text { treatment with DOX }\end{array}$ & n.d. & $\begin{array}{c}\text { PROTECTIVE } \\
\text { DHA pretreatment: Inhibition } \\
\text { of DOX-induced }\left(\mathrm{Ca}^{2+}\right)_{\mathrm{i}} \text { increase }\end{array}$ & [119] \\
\hline $\begin{array}{l}\text { H9C2 cardiomyoblast } \\
\text { cell line }\end{array}$ & $\begin{array}{c}1 \mu \mathrm{M} \text { DOX in DMEM- } 10 \% \\
\text { FBS }(24 \mathrm{~h}) \text { after } 24 \mathrm{~h} \\
\text { EPA/DHA treatment }\end{array}$ & $\begin{array}{c}\text { Pre-treatment with } \\
100 \mu \mathrm{M} \text { EPA or } 50 \mu \mathrm{M} \\
\text { DHA in DMEM-0.1\% BSA } \\
(24 \mathrm{~h})\end{array}$ & none & $\begin{array}{l}\text { No treatment with } \omega-3 \\
\text { PUFA } \pm \text { treatment } \\
\text { with DOX }\end{array}$ & n.d. & $\begin{array}{c}\text { PROTECTIVE } \\
\text { EPA or DHA pretreatment: } \\
\text { prevention of DOX-induced: } \\
\text {-decrease in UCP2 levels } \\
\text {-increase in ROS production } \\
\text {-MMP decrease }\end{array}$ & {$[80]$} \\
\hline $\begin{array}{l}\mathrm{H} 9 \mathrm{C} 2 \text { cardiomyoblast } \\
\text { cell line }\end{array}$ & $\begin{array}{c}5 \mu \mathrm{M} \text { DOX in DMEM-10\% } \\
\text { FBS }(4 \mathrm{~h})\end{array}$ & $\begin{array}{l}\text { Co-treatment with } 10 \mu \mathrm{M} \\
\text { DHA-FFA }(4 \mathrm{~h})\end{array}$ & none & $\begin{array}{l}\text { No treatment with DHA } \\
\pm \text { treatment with DOX }\end{array}$ & Increased viability & $\begin{array}{c}\text { PROTECTIVE } \\
\text { DHA co-treatment: } \\
\text { suppression of DOX-induced: } \\
\text {-ROS production; } \\
\text {-expression of TNF- } \alpha \text {, IL-6, MCP-1, } \\
\text { iNOS, and IL-1 } \beta ; \\
\text {-phosphorylation of IkB- } \alpha \text { and } \\
\text { NF-kB/P65 } \\
\end{array}$ & {$[82]$} \\
\hline $\begin{array}{l}\mathrm{H} 9 \mathrm{C} 2 \text { cardiomyoblast } \\
\text { cell line }\end{array}$ & $\begin{array}{c}20 \mathrm{mM} \text { DOX in } \\
\text { DMEM-10\% FBS (1 h) }\end{array}$ & $\begin{array}{c}\text { After DOX treatment: } \\
1.25 \mathrm{mg} / \mathrm{mL} \text { SO-loaded } \\
\text { Va-g-Ch microparticles } \\
\text { (SO-M) }\end{array}$ & none & No treatments & n.d. * & $\begin{array}{c}\text { PROTECTIVE } \\
\text { SO-M treatment: } \\
\text { suppression of DOX-induced: } \\
\text {-caspase-3 activation; } \\
\text {-increased expression of NF- } \mathrm{kB}\end{array}$ & {$[83]$} \\
\hline
\end{tabular}

ATC, Antracyclines; BSA, bovine serum albumin; DHA-FFA, DHA bound free fatty acid; DMEM, Dulbecco modified minimum essential medium; DOX, doxorubicin; IL, interleukin; MCP-1, monocyte chemoattractant protein 1; MMP, mitochondrial membrane potential; n.d., not determined; SO, sardine oil; SO-M, sardine oil-loaded microparticles; TNF- $\alpha$, tumor necrosis factor $\alpha$; UCP2: uncoupling protein 2; Va-g-Ch: vanillic acid-grafted chitosan; ${ }^{*}$ Higher cardiomyocyte viability, lower oxygen reactive species (ROS) production, and MMP near to normal level, evaluated only with SO-M treatment alone, compared to DOX-treatment alone. 
Healthy cardiac effects were also obtained in other works using models that differed for many aspects from those so far analyzed. In one of them, Xue et al. [81] (Table 1) administered EPA and DHA (0.19 $\mathrm{g} / \mathrm{kg}$ body weight EPA and $0.18 \mathrm{~g} / \mathrm{kg}$ body weight DHA) every other day in a parenteral solution via tail vein of anesthetized rats bearing syngeneic mammary adenocarcinoma xenografts. This treatment was performed one week before and seven weeks after the DOX treatment with a cumulative dose of $6 \mathrm{mg} / \mathrm{kg}$. Despite the difficulty in comparing this model to the others so far analyzed, it is interesting since it reflects the possible supplementations with $\omega-3$ in oncological patients undergoing ATC therapy. In this case, mixed effects were obtained regarding the parenteral infusion with EPA and DHA. Neutral effects were observed for some parameters, such as the DOX-induced increase in the left ventricular end-diastolic and end-systolic dimensions (LVEDD and LVESD), DOX-induced lipid peroxidation, antioxidant factors and apoptosis in the myocardium. Among the positive effects, there were the prevention of the DOX-induced increase in the plasma cardiac troponin I (cTNI) levels, and a trend for better preserved left ventricular function (left ventricular fractional shortening, LVES, and left ventricular ejection fraction, LVEF) and morphology (suppressing DOX-induced LV dilation). The in vivo work by Schjøtt et al. [116] is difficult to compare with other in vivo studies. It was performed by supplementing (for two weeks) rats by gavage with very low daily doses of EPA or DHA-ethyl esters (EPA or DHA, approximately $0.03-0.045 \mathrm{~g} / \mathrm{kg}$ body weight, suspended in carboxymethylcellulose), and their effect was evaluated on the hearts isolated and perfused with ex vivo DOX. Although the experimental conditions were so peculiar, it is particularly worth noting that extremely low doses of EPA or DHA resulted to be protective (by decreasing the aortic pressure) on the hearts challenged ex vivo with DOX. In another in vivo work, Yu et al. [117] (Table 1) investigated the effect of $\alpha$-linolenic acid (ALA, 18:3 $\omega$-3), the essential fatty acid precursor of EPA and DHA. Although ALA is known to be scarcely converted in vivo into the longer chain PUFA, EPA and DHA [123], it should be taken into account that experiments performed in rats have demonstrated that different tissues possess different abilities to endogenously synthesize long-chain $\omega$-3 PUFA from ALA. In particular, the heart is one of the sites displaying the highest level of endogenous synthesis of long-chain $\omega$-3 PUFA from ALA [118]. A very low dose of ALA ( $0.05 \mathrm{~g} / \mathrm{kg}$ body weight) was administered by gavage to rats three days before and a week after the DOX treatment (cumulative dose: $17.5 \mathrm{mg} / \mathrm{kg}$ ) [117]. The ALA treatment prevented the alterations induced by DOX on numerous morphologic and functional parameters at the cardiac level. Moreover, these results agree in suggesting that relatively low doses of $\omega-3$ PUFA may be more effective in preventing chemotherapy-induced side-effects in the heart. It is worth pointing out that, in this case, ALA supplementation decreased the DOX-induced oxidative stress, confirming the result observed in the study by Uygur et al. [79], where (see above) low doses of EFA capsules (at high levels of EPA and DHA, but also containing ALA) were administered. On the contrary, the parenteral solution infused by Xue et al. [81], and containing comparable amounts of EPA + DHA, did not affect the other several investigated parameters of oxidative stress. On the other hand, lipoperoxidation (LP) was found increased in the heart tissue and the level of vitamin E decreased by Matsui et al. [112], and these modifications were included by the authors among the harmful effects exerted by these fatty acids at cardiovascular levels. Interestingly, in a work [118] (Table 1) where rats were subject to chemically-induced mammary carcinogenesis, a supplementation with doses of DHASCO oil furnishing approximately $3.5 \mathrm{~g}$ DHA intake/ $\mathrm{kg}$ body weight $[121,124]$, prior and during the EPI treatment, did not induce any increase in LP in normal tissue, including the cardiac tissue. Meanwhile, the cardiac total antioxidant activity, as well as that of the antioxidant enzymes SOD and GPx was found to be increased. On the contrary, LP increased remarkably in the tumor tissue, due to the lack of adjustment of the antioxidant reserve, which may potentially improve the outcome of ATC chemotherapy. Moreover, two in vitro investigations (Table 2) [80,82] found that EPA and DHA added to the culture medium had the potential to suppress the DOX-induced ROS production of $\mathrm{H} 9 \mathrm{C} 2$ cardiomyoblast cell line. It was also found that the treatment of cardiomyoblasts in vitro with DHA [82] or sardine oil embedded in vanillic acid-chitosan microparticles [83] could also 
suppress the DOX-induced expression/activation of NF- $\mathrm{KB}[82,83]$, a transcription factor activated by the increase of ROS at the cellular level, and, furthermore, involved in the transcription of inflammatory cytokines. Compatibly, DHA was also found to suppress [82] the DOX-induced expression of TNF- $\alpha$, IL-6, MCP-1 and IL-1 $\beta$. In the same work [82] DHA also reduced the DOX-mediated expression of the enzyme iNOS, related to the generation of the powerful oxidant peroxynitrite from NO. Some of these in vitro studies (Table 2) reported the contrasting effect exerted by $\omega-3$ treatment on phenomena related to the DOX-induced apoptosis, i.e., the decrease of the mitochondrial membrane potential, and caspase-3 activation [80,83]. Lastly, one of these studies reported the $\omega-3$ ability to suppress the increase in $\left(\mathrm{Ca}^{2+}\right)_{\mathrm{i}}$ related to the alteration induced by DOX in sarcoplasmic reticulum $\mathrm{Ca}^{2+}$ release [119].

\section{Conclusions}

Overall, the extreme variability in the experimental in vivo models makes their analysis and comparison very difficult. However, from the experiments performed in rats, it is possible to conclude that the level of $\omega-3$ PUFA intake represents one of the main factors determining whether they exert protection against ATC-induced cardiotoxicity. We have observed that relatively low doses administered to rats with the diet $(0.5 \mathrm{~g} / \mathrm{kg}$ body weight for ALA, and ranging from 0.2 to $1.5 \mathrm{~g} / \mathrm{kg}$ body weight for EPA + DHA or DHA alone) could prevent the development and progression of DOX-mediated cardiotoxicity in vivo. Even lower doses of $\omega-3$ PUFA given to rats in vivo (0.030-0.045 $\mathrm{g} / \mathrm{kg}$ body weight) resulted in cardioprotective effects in hearts excised and perfused ex vivo with DOX. On the contrary, higher doses (2.0-3.0 $\mathrm{g} \omega-3 / \mathrm{kg}$ body weight) exacerbated the harmful effects of DOX at the cardiac level. Interestingly, however, even higher doses of EPA and/or DHA (4.5 g EPA + DHA $/ \mathrm{kg}$ body weight or $6.0 \mathrm{~g}$ DHA $/ \mathrm{kg} /$ body weight) appeared neutral, not adding further risks to the cardiotoxicity if associated to a treatment with EPI, an ATC showing less cardiotoxicity than DOX. Thus, these outcomes suggest that, to obtain a protective effect, relatively low doses of $\omega$-3 PUFA should be administered (lower than $2.0 \mathrm{~g} /$ body weight in rats). These doses would probably not be sufficient to induce cytotoxicity driven by lipoperoxidation and high level of oxidative stress that, conversely, are known to be induced by high concentrations of these fatty acids [125]. On the contrary, as demonstrated by the outcomes of both the in vivo and in vitro studies, low and protective doses may not alter or may even decrease the ATC-induced lipoperoxidation. They may also not affect or even reduce the level of ATC-induced ROS formation, and, lastly, may not modify the ATC-induced decrease in antioxidant enzyme expressions or activities, or even induce them.

Moreover, in a future prospective, it should be emphasized that, although the mechanisms of cytotoxicity related to the oxidative stress are those mainly investigated by the ATC/ $\omega-3$ PUFA combined studies, recently, several other important and more specific mechanisms have been sought to explain the health effects of $\omega-3$ PUFA, both in general and at CV levels (Figure 1). Some of them involve their anti-inflammatory activities, as well as their ability to negatively modulate some molecular pathways, such as those leading to the activation of NF-KB or those involved in autophagy [126-129], or to influence the epigenetic regulation $[7,130]$. Interestingly, these mechanisms represent some of those more recently involved in the ATC-induced cardiotoxicity. Since they often appear to be modulated by ATC and $\omega-3$ PUFA in an opposite way, it would be worthwhile to investigate their involvement in future combined studies examining the effects $\omega-3$ PUFA and ATC at CV level. Remarkably, it has been recently observed that one of the consequences of iron overload at the hepatic level is the inhibition of the $\Delta-5$ and $\Delta-6$ desaturases, which prevents the endogenous synthesis of LC- $\omega-3$ PUFA, and leads to their depletion with harmful consequences for the cells [131]. Since iron overload is also considered one of the main mechanisms of ATC-induced cardiotoxicity, it would be stimulating to investigate whether it may suppress the synthesis and the level of LC- $\omega-3$ PUFA also at cardiac levels, and if the impaired synthesis could be related to ATC-cardiotoxicity. 


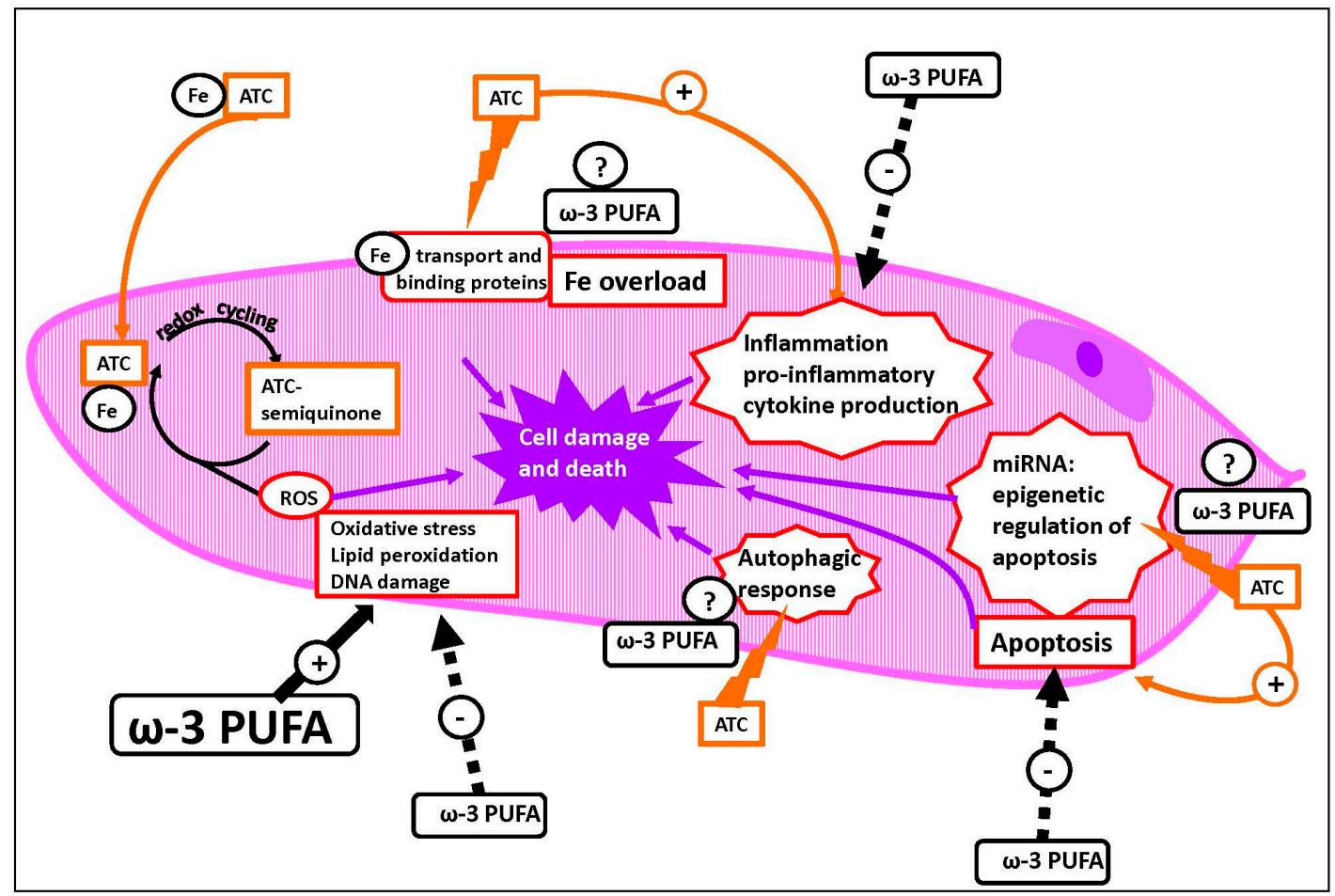

Figure 1. Potential protective effects of $\omega-3$ polyunsaturated fatty acids (PUFA) against anthracyclines (ATC)-induced cardiotoxicity. Diagram of a cardiomyocyte and some mechanisms of ATC-induced cardiotoxicity that were found to be either activated or inhibited by $\omega-3$ PUFA ( $\omega-3$ PUFA) (indicated by plain black arrows with + sign or dashed black arrows with - sign, respectively), or that could be potentially affected by these fatty acids (see in the text for more details). The question marks indicate some mechanisms that we have suggested, and through which $\omega-3$ PUFA could potentially prevent ATC-induced cardiotoxicity toxicity (see in the text for more details). Orange arrows indicate mechanisms of ATC-induced cardiotoxicity. Purple arrows indicate pathways leading to cell death.

Acknowledgments: This work was supported in part by grants Linea D1 2015, Linea D.3.2 2013 and D.3.2 2015 to Gabriella Calviello from Università Cattolica del Sacro Cuore, Rome, Italy, within its program of promotion and diffusion of scientific research.

Conflicts of Interest: The authors declare no conflict of interest.

\section{References}

1. Lee, J.Y.; Sim, T.B.; Lee, J.E.; Na, H.K. Chemopreventive and chemotherapeutic effects of fish oil derived $\omega-3$ polyunsaturated fatty acids on colon carcinogenesis. Clin. Nutr. Res. 2017, 6, 147-160. [CrossRef] [PubMed]

2. Liu, J.; Ma, D.W. The role of $n-3$ polyunsaturated fatty acids in the prevention and treatment of breast cancer. Nutrients 2014, 6, 5184-5223. [CrossRef] [PubMed]

3. Endo, J.; Arita, M. Cardioprotective mechanism of $\omega-3$ polyunsaturated fatty acids. J. Cardiol. 2016, 67, $22-27$. [CrossRef] [PubMed]

4. Devassy, J.G.; Leng, S.; Gabbs, M.; Monirujjaman, M.; Aukema, H.M. $\Omega-3$ polyunsaturated fatty acids and oxylipins in neuroinflammation and management of Alzheimer disease. Adv. Nutr. 2016, 7, 905-916. [CrossRef] [PubMed]

5. Calviello, G.; Su, H.M.; Weylandt, K.H.; Fasano, E.; Serini, S.; Cittadini, A. Experimental evidence of $\omega-3$ polyunsaturated fatty acid modulation of inflammatory cytokines and bioactive lipid mediators: Their potential role in inflammatory, neurodegenerative, and neoplastic diseases. BioMed Res. Int. 2013, 2013, 743171. [CrossRef] [PubMed] 
6. Ma, D.W.; Seo, J.; Davidson, L.A.; Callaway, E.S.; Fan, Y.Y.; Lupton, J.R.; Chapkin, R.S. n-3 PUFA alter caveolae lipid composition and resident protein localization in mouse colon. FASEB J. 2004, 18, 1040-1042. [CrossRef] [PubMed]

7. Serini, S.; Ottes Vasconcelos, R.; Fasano, E.; Calviello, G. Epigenetic regulation of gene expression and M2 macrophage polarization as new potential $\omega-3$ polyunsaturated fatty acid targets in colon inflammation and cancer. Expert Opin. Ther. Targets 2016, 20, 843-858. [CrossRef] [PubMed]

8. Serini, S.; Calviello, G. Reduction of oxidative/nitrosative stress in brain and its involvement in the neuroprotective effect of $n-3$ PUFA in Alzheimer's disease. Curr. Alzheimer Res. 2016, 13, 123-134. [CrossRef] [PubMed]

9. Eltweri, A.M.; Thomas, A.L.; Metcalfe, M.; Calder, P.C.; Dennison, A.R.; Bowrey, D.J. Potential applications of fish oils rich in $\omega-3$ polyunsaturated fatty acids in the management of gastrointestinal cancer. Clin. Nutr. 2017, 36, 65-78. [CrossRef] [PubMed]

10. Calviello, G.; Serini, S.; Piccioni, E. $n-3$ polyunsaturated fatty acids and the prevention of colorectal cancer: Molecular mechanisms involved. Curr. Med. Chem. 2007, 14, 3059-3069. [CrossRef] [PubMed]

11. Serini, S.; Calviello, G. Modulation of Ras/ERK and phosphoinositide signaling by long-chain $n$-3 PUFA in breast cancer and their potential complementary role in combination with targeted drugs. Nutrients 2017, 9, 185. [CrossRef] [PubMed]

12. Serini, S.; Piccioni, E.; Merendino, N.; Calviello, G. Dietary polyunsaturated fatty acids as inducers of apoptosis: Implications for cancer. Apoptosis 2009, 14, 135-152. [CrossRef] [PubMed]

13. Serini, S.; Ottes Vasconcelos, R.; Fasano, E.; Calviello, G. How plausible is the use of dietary $n-3$ PUFA in the adjuvant therapy of cancer? Nutr. Res. Rev. 2016, 29, 102-125. [CrossRef] [PubMed]

14. Merendino, N.; Costantini, L.; Manzi, L.; Molinari, R.; D’Eliseo, D.; Velotti, F. Dietary w-3 polyunsaturated fatty acid DHA: A potential adjuvant in the treatment of cancer. BioMed Res. Int. 2013, 2013, 310186. [CrossRef] [PubMed]

15. Ghigo, A.; Li, M.; Hirsch, E. New signal transduction paradigms in anthracycline-induced cardiotoxicity. Biochim. Biophys. Acta 2016, 1863, 1916-1925. [CrossRef] [PubMed]

16. World Health Organization. Available online: http://www.who.int/mediacentre/factsheets/fs317/en/ (accessed on 7 November 2017).

17. Ravera, A.; Carubelli, V.; Sciatti, E.; Bonadei, I.; Gorga, E.; Cani, D.; Vizzardi, E.; Metra, M.; Lombardi, C. Nutrition and cardiovascular disease: Finding the perfect recipe for cardiovascular health. Nutrients 2016, 8, 363. [CrossRef] [PubMed]

18. Spencer, R.M.; Heidecker, B.; Ganz, P. Behavioral cardiovascular risk factors-effect of physical activity and cardiorespiratory fitness on cardiovascular outcomes. Circ. J. 2016, 80, 34-43. [CrossRef] [PubMed]

19. Bowen, K.J.; Harris, W.S.; Kris-Etherton, P.M. $\Omega-3$ fatty acids and cardiovascular disease: Are there benefits? Curr. Treat. Options Cardiovasc. Med. 2016, 18, 69. [CrossRef] [PubMed]

20. Calder, P.C. $\Omega-3$ polyunsaturated fatty acids and inflammatory processes: Nutrition or pharmacology? Br. J. Clin. Pharmacol. 2013, 75, 645-662. [CrossRef] [PubMed]

21. Yang, Z.H.; Emma-Okon, B.; Remaley, A.T. Dietary marine-derived long-chain monounsaturated fatty acids and cardiovascular disease risk: A mini review. Lipids Health Dis. 2016, 15, 201. [CrossRef] [PubMed]

22. Chiesa, G.; Busnelli, M.; Manzini, S.; Parolini, C. Nutraceuticals and bioactive components from fish for dyslipidemia and cardiovascular risk reduction. Mar. Drugs 2016, 14, 113. [CrossRef] [PubMed]

23. Weisman, D.; Beinart, R.; Erez, A.; Koren-Morag, N.; Goldenberg, I.; Eldar, M.; Glikson, M.; Luria, D. Effect of supplemented intake of $\omega-3$ fatty acids on arrhythmias in patients with ICD: Fish oil therapy may reduce ventricular arrhythmia. J. Interv. Card. Electrophysiol. 2017, 49, 255-261. [CrossRef] [PubMed]

24. Phang, M.; Lincz, L.F.; Garg, M.L. Eicosapentaenoic and docosahexaenoic acid supplementations reduce platelet aggregation and hemostatic markers differentially in men and women. J. Nutr. 2013, 143, 457-463. [CrossRef] [PubMed]

25. Li, X.; Ballantyne, L.L.; Che, X.; Mewburn, J.D.; Kang, J.X.; Barkley, R.M.; Murphy, R.C.; Yu, Y.; Funk, C.D. Endogenously generated $\omega-3$ fatty acids attenuate vascular inflammation and neointimal hyperplasia by interaction with free fatty acid receptor 4 in mice. J. Am. Heart. Assoc. 2015, 4, e001856. [CrossRef] [PubMed]

26. Backes, J.; Anzalone, D.; Hilleman, D.; Catini, J. The clinical relevance of $\omega-3$ fatty acids in the management of hypertriglyceridemia. Lipids Health Dis. 2016, 15, 118. [CrossRef] [PubMed] 
27. Colussi, G.; Catena, C.; Novello, M.; Bertin, N.; Sechi, L.A. Impact of $\omega-3$ polyunsaturated fatty acids on vascular function and blood pressure: Relevance for cardiovascular outcomes. Nutr. Metab. Cardiovasc. Dis. 2017, 27, 191-200. [CrossRef] [PubMed]

28. Sauder, K.A.; Skulas-Ray, A.C.; Campbell, T.S.; Johnson, J.A.; Kris-Etherton, P.M.; West, S.G. Effects of $\omega-3$ fatty acid supplementation on heart rate variability at rest and during acute stress in adults with moderate hypertriglyceridemia. Psychosom. Med. 2013, 75, 382-389. [CrossRef] [PubMed]

29. Hansen, A.L.; Dahl, L.; Olson, G.; Thornton, D.; Graff, I.E.; Frøyland, L.; Thayer, J.F.; Pallesen, S. Fish consumption, sleep, daily functioning, and heart rate variability. J. Clin. Sleep Med. 2014, 10, 567-575. [CrossRef] [PubMed]

30. Biondo, P.D.; Brindley, D.N.; Sawyer, M.B.; Field, C.J. The potential for treatment with dietary long-chain polyunsaturated n-3 fatty acids during chemotherapy. J. Nutr. Biochem. 2008, 19, 787-796. [CrossRef] [PubMed]

31. Serini, S.; Piccioni, E.; Calviello, G. $w-3$ PUFAs and colon cancer: Experimental studies and human interventional trials. In Dietary $\Omega-3$ Polyunsaturated Fatty Acids and Cancer; Calviello, G., Serini, S., Eds.; Springer: New York, NY, USA, 2010; Volume 1, pp. 67-89. ISBN 978-90-481-3578-3.

32. Stillwell, W.; Jenski, L.J.; Crump, F.T.; Ehringer, W. Effect of docosahexaenoic acid on mouse mitochondrial membrane properties. Lipids 1997, 32, 497-506. [CrossRef] [PubMed]

33. Turk, H.F.; Chapkin, R.S. Membrane lipid raft organization is uniquely modified by $n-3$ polyunsaturated fatty acids. Prostaglandins Leukot. Essent. Fat. Acids 2013, 88, 43-47. [CrossRef] [PubMed]

34. Calviello, G.; Serini, S.; Palozza, P. n-3 polyunsaturated fatty acids as signal transduction modulators and therapeutical agents in cancer. Curr. Signal Transdust. Ther. 2006, 1, 255-271. [CrossRef]

35. Gillet, L.; Roger, S.; Bougnoux, P.; Le Guennec, J.Y.; Besson, P. Beneficial effects of $\omega$-3 long-chain fatty acids in breast cancer and cardiovascular diseases: Voltage-gated sodium channels as a common feature? Biochimie 2011, 93, 4-6. [CrossRef] [PubMed]

36. Ferrier, G.R.; Redondo, I.; Zhu, J.; Murphy, M.G. Differential effects of docosahexaenoic acid on contractions and L-type $\mathrm{Ca}^{2+}$ current in adult cardiac myocytes. Cardiovasc. Res. 2002, 54, 601-610. [CrossRef]

37. Sansbury, B.E.; Spite, M. Resolution of acute inflammation and the role of resolvins in immunity, thrombosis, and vascular biology. Circ. Res. 2016, 119, 113-130. [CrossRef] [PubMed]

38. Wu, B.; Mottola, G.; Schaller, M.; Upchurch, G.R., Jr.; Conte, M.S. Resolution of vascular injury: Specialized lipid mediators and their evolving therapeutic implications. Mol. Asp. Med. 2017, 58, 72-82. [CrossRef] [PubMed]

39. Zivkovic, A.M.; Telis, N.; German, J.B.; Hammock, B.D. Dietary $\omega-3$ fatty acids aid in the modulation of inflammation and metabolic health. Calif. Agric. 2011, 65, 106-111. [CrossRef] [PubMed]

40. Russo, G.L. Dietary n-6 and n-3 polyunsaturated fatty acids: From biochemistry to clinical implications in cardiovascular prevention. Biochem. Pharmacol. 2009, 77, 937-946. [CrossRef] [PubMed]

41. Serhan, C.N. Treating inflammation and infection in the 21st century: New hints from decoding resolution mediators and mechanisms. FASEB J. 2017, 31, 1273-1288. [CrossRef] [PubMed]

42. Calder, P.C. The role of marine $\omega-3(n-3)$ fatty acids in inflammatory processes, atherosclerosis and plaque stability. Mol. Nutr. Food Res. 2012, 56, 1073-1080. [CrossRef] [PubMed]

43. Wong, A.T.; Chan, D.C.; Ooi, E.M.; Ng, T.W.; Watts, G.F.; Barrett, P.H. $\Omega-3$ fatty acid ethyl ester supplementation decreases very-low-density lipoprotein triacylglycerol secretion in obese men. Clin. Sci. Lond. 2013, 125, 45-51. [CrossRef] [PubMed]

44. Sampath, H.; Ntambi, J.M. Polyunsaturated fatty acid regulation of genes of lipid metabolism. Annu. Rev. Nutr. 2005, 25, 317-340. [CrossRef] [PubMed]

45. Kimura, R.; Takahashi, N.; Lin, S.; Goto, T.; Murota, K.; Nakata, R.; Inoue, H.; Kawada, T. DHA attenuates postprandial hyperlipidemia via activating PPAR $\alpha$ in intestinal epithelial cells. J. Lipid Res. 2013, 54, 3258-3268. [CrossRef] [PubMed]

46. Adkins, Y.; Kelley, D.S. Mechanisms underlying the cardioprotective effects of $\omega$-3 polyunsaturated fatty acids. J. Nutr. Biochem. 2010, 21, 781-792. [CrossRef] [PubMed]

47. Newell, M.; Baker, K.; Postovit, L.M.; Field, C.J. A critical review on the effect of docosahexaenoic acid (DHA) on cancer cell cycle. Int. J. Mol. Sci. 2017, 18, 1784. [CrossRef] [PubMed]

48. Song, E.A.; Kim, H. Docosahexaenoic acid induces oxidative DNA damage and apoptosis, and enhances the chemosensitivity of cancer cells. Int. J. Mol. Sci. 2016, 17, 1257. [CrossRef] [PubMed] 
49. Spencer, L.; Mann, C.; Metcalfe, M.; Webb, M.; Pollard, C.; Spencer, D.; Berry, D.; Steward, W.; Dennison, A. The effect of $\omega-3$ FAs on tumour angiogenesis and their therapeutic potential. Eur. J. Cancer 2009, 45, 2077-2086. [CrossRef] [PubMed]

50. D'Eliseo, D.; Velotti, F. $\Omega-3$ fatty acids and cancer cell cytotoxicity: Implications for multi-targeted cancer therapy. J. Clin. Med. 2016, 5, 15. [CrossRef] [PubMed]

51. Shaikh, S.R. Biophysical and biochemical mechanisms by which dietary N-3 polyunsaturated fatty acids from fish oil disrupt membrane lipid rafts. J. Nutr. Biochem. 2012, 23, 101-105. [CrossRef] [PubMed]

52. Schley, P.D.; Brindley, D.N.; Field, C.J. (n-3) PUFA alter raft lipid composition and decrease epidermal growth factor receptor levels in lipid rafts of human breast cancer cells. J. Nutr. 2007, 137, 548-553. [PubMed]

53. Schley, P.D.; Jijon, H.B.; Robinson, L.E.; Field, C.J. Mechanisms of $\omega-3$ fatty acid-induced growth inhibition in MDA-MB-231 human breast cancer cells. Breast Cancer Res. Treat. 2005, 92, 187-195. [CrossRef] [PubMed]

54. Ding, W.Q.; Liu, B.; Vaught, J.L.; Palmiter, R.D.; Lind, S.E. Clioquinol and docosahexaenoic acid act synergistically to kill tumor cells. Mol. Cancer Ther. 2006, 5, 1864-1872. [CrossRef] [PubMed]

55. Ghosh-Choudhury, T.; Mandal, C.C.; Woodruff, K.; St Clair, P.; Fernandes, G.; Choudhury, G.G.; Ghosh-Choudhury, N. Fish oil targets PTEN to regulate NFKB for downregulation of anti-apoptotic genes in breast tumor growth. Breast Cancer Res. Treat. 2009, 118, 213-228. [CrossRef] [PubMed]

56. Han, L.; Zhang, Y.; Meng, M.; Cheng, D.; Wang, C. Eicosapentaenoic acid induced SKOV-3 cell apoptosis through ERK1/2-mTOR-NF-kB pathways. Anticancer Drugs 2016, 27, 635-642. [CrossRef] [PubMed]

57. Mazière, C.; Conte, M.A.; Degonville, J.; Ali, D.; Mazière, J.C. Cellular enrichment with polyunsaturated fatty acids induces an oxidative stress and activates the transcription factors AP1 and NFkB. Biochem. Biophys. Res. Commun. 1999, 265, 116-122. [CrossRef] [PubMed]

58. Chapkin, R.S.; Hong, M.Y.; Fan, Y.Y.; Davidson, L.A.; Sanders, L.M.; Henderson, C.E.; Barhoumi, R.; Burghardt, R.C.; Turner, N.D.; Lupton, J.R. Dietary n-3 PUFA alter colonocyte mitochondrial membrane composition and function. Lipids 2002, 37, 193-199. [CrossRef] [PubMed]

59. Erejuwa, O.O.; Sulaiman, S.A.; Ab Wahab, M.S. Evidence in support of potential applications of lipid peroxidation products in cancer treatment. Oxid. Med. Cell Longev. 2013, 2013, 931251. [CrossRef] [PubMed]

60. Angeli, J.P.; Garcia, C.C.; Sena, F.; Freitas, F.P.; Miyamoto, S.; Medeiros, M.H.; Di Mascio, P. Lipid hydroperoxide-induced and hemoglobin-enhanced oxidative damage to colon cancer cells. Free Radic. Biol. Med. 2011, 51, 503-515. [CrossRef] [PubMed]

61. Falconer, J.S.; Ross, J.A.; Fearon, K.C.; Hawkins, R.A.; O’Riordain, M.G.; Carter, D.C. Effect of eicosapentaenoic acid and other fatty acids on the growth in vitro of human pancreatic cancer cell lines. Br. J. Cancer 1994, 69, 826-832. [CrossRef] [PubMed]

62. Bagga, D.; Wang, L.; Farias-Eisner, R.; Glaspy, J.A.; Reddy, S.T. Differential effects of prostaglandin derived from $\omega-6$ and $\omega-3$ polyunsaturated fatty acids on COX-2 expression and IL-6 secretion. Proc. Natl. Acad. Sci. USA 2003, 100, 1751-1756. [CrossRef] [PubMed]

63. Vaughan, V.C.; Hassing, M.R.; Lewandowski, P.A. Marine polyunsaturated fatty acids and cancer therapy. Br. J. Cancer 2013, 108, 486-492. [CrossRef] [PubMed]

64. Sunpaweravong, S.; Puttawibul, P.; Ruangsin, S.; Laohawiriyakamol, S.; Sunpaweravong, P.; Sangthawan, D.; Pradutkanchana, J.; Raungkhajorn, P.; Geater, A. Randomized study of antiinflammatory and immune-modulatory effects of enteral immunonutrition during concurrent chemoradiotherapy for esophageal cancer. Nutr. Cancer 2014, 66, 1-5. [CrossRef] [PubMed]

65. Zhelev, Z.; Ivanova, D.; Lazarova, D.; Aoki, I.; Bakalova, R.; Saga, T. Docosahexaenoic acid sensitizes leukemia lymphocytes to Barasertib and Everolimus by ROS-dependent mechanism without affecting the level of ROS and viability of normal lymphocytes. Anticancer Res. 2016, 36, 1673-1682. [PubMed]

66. Siddiqui, R.A.; Harvey, K.A.; Xu, Z.; Bammerlin, E.M.; Walker, C.; Altenburg, J.D. Docosahexaenoic acid: A natural powerful adjuvant that improves efficacy for anticancer treatment with no adverse effects. Biofactors 2011, 37, 399-412. [CrossRef] [PubMed]

67. Gelsomino, G.; Corsetto, P.A.; Campia, I.; Montorfano, G.; Kopecka, J.; Castella, B.; Gazzano, E.; Ghigo, D.; Rizzo, A.M.; Riganti, C. Omega 3 fatty acids chemosensitize multidrug resistant colon cancer cells by down-regulating cholesterol synthesis and altering detergent resistant membranes composition. Mol. Cancer 2013, 12, 137. [CrossRef] [PubMed] 
68. Jiao, Y.; Hannafon, B.N.; Zhang, R.R.; Fung, K.M.; Ding, W.Q. Docosahexaenoic acid and disulfiram act in concert to kill cancer cells: A mutual enhancement of their anticancer actions. Oncotarget 2017, 8, 17908-17920. [CrossRef] [PubMed]

69. Gao, K.; Liang, Q.; Zhao, Z.H.; Li, Y.F.; Wang, S.F. Synergistic anticancer properties of docosahexaenoic acid and 5-fluorouracil through interference with energy metabolism and cell cycle arrest in human gastric cancer cell line AGS cells. World J. Gastroenterol. 2016, 22, 2971-2980. [CrossRef] [PubMed]

70. Sheng, H.; Chen, X.; Liu, B.; Li, P.; Cao, W. $\Omega-3$ polyunsaturated fatty acids enhance cisplatin efficacy in gastric cancer cells by inducing apoptosis via ADORA1. Anticancer Agents Med. Chem. 2016, 16, 1085-1092. [CrossRef] [PubMed]

71. Chauvin, L.; Goupille, C.; Blanc, C.; Pinault, M.; Domingo, I.; Guimaraes, C.; Bougnoux, P.; Chevalier, S.; Mahéo, K. Long chain $n-3$ polyunsaturated fatty acids increase the efficacy of docetaxel in mammary cancer cells by downregulating Akt and PKC $/$ / $\delta$-induced ERK pathways. Biochim. Biophys. Acta 2016, 1861, 380-390. [CrossRef] [PubMed]

72. Abdi, J.; Garssen, J.; Faber, J.; Redegeld, F.A. $\Omega-3$ fatty acids, EPA and DHA induce apoptosis and enhance drug sensitivity in multiple myeloma cells but not in normal peripheral mononuclear cells. J. Nutr. Biochem. 2014, 25, 1254-1262. [CrossRef] [PubMed]

73. Mason, J.K.; Fu, M.; Chen, J.; Thompson, L.U. Flaxseed oil enhances the effectiveness of trastuzumab in reducing the growth of HER2-overexpressing human breast tumors (BT-474). J. Nutr. Biochem. 2015, 26, 16-23. [CrossRef] [PubMed]

74. Bougnoux, P.; Hajjaji, N.; Ferrasson, M.N.; Giraudeau, B.; Couet, C.; Le Floch, O. Improving outcome of chemotherapy of metastatic breast cancer by docosahexaenoic acid: A phase II trial. Br. J. Cancer 2009, 101, 1978-1985. [CrossRef] [PubMed]

75. Murphy, R.A.; Mourtzakis, M.; Chu, Q.S.; Baracos, V.E.; Reiman, T.; Mazurak, V.C. Supplementation with fish oil increases first-line chemotherapy efficacy in patients with advanced non-small cell lung cancer. Cancer 2011, 117, 3774-3780. [CrossRef] [PubMed]

76. Miyata, H.; Yano, M.; Yasuda, T.; Yamasaki, M.; Murakami, K.; Makino, T.; Nishiki, K.; Sugimura, K.; Motoori, M.; Shiraishi, O.; et al. Randomized study of the clinical effects of $\omega-3$ fatty acid-containing enteral nutrition support during neoadjuvant chemotherapy on chemotherapy-related toxicity in patients with esophageal cancer. Nutrition 2017, 33, 204-210. [CrossRef] [PubMed]

77. Shirai, Y.; Okugawa, Y.; Hishida, A.; Ogawa, A.; Okamoto, K.; Shintani, M.; Morimoto, Y.; Nishikawa, R.; Yokoe, T.; Tanaka, K.; et al. Fish oil-enriched nutrition combined with systemic chemotherapy for gastrointestinal cancer patients with cancer cachexia. Sci. Rep. 2017, 7, 4826. [CrossRef] [PubMed]

78. Teng, L.L.; Shao, L.; Zhao, Y.T.; Yu, X.; Zhang, D.F.; Zhang, H. The beneficial effect of $n-3$ polyunsaturated fatty acids on doxorubicin-induced chronic heart failure in rats. J. Int. Med. Res. 2010, 38, 940-948. [CrossRef] [PubMed]

79. Uygur, R.; Aktas, C.; Tulubas, F.; Alpsoy, S.; Topcu, B.; Ozen, O.A. Cardioprotective effects of fish $w-3$ fatty acids on doxorubicin-induced cardiotoxicity in rats. Hum. Exp. Toxicol. 2014, 33, 435-445. [CrossRef] [PubMed]

80. Hsu, H.C.; Chen, C.Y.; Chen, M.F. N-3 polyunsaturated fatty acids decrease levels of doxorubicin-induced reactive oxygen species in cardiomyocytes-Involvement of uncoupling protein UCP2. J. Biomed. Sci. 2014, 21, 101. [CrossRef] [PubMed]

81. Xue, H.; Ren, W.; Denkinger, M.; Schlotzer, E.; Wischmeyer, P.E. Nutrition modulation of cardiotoxicity and anticancer efficacy related to Doxorubicin chemotherapy by glutamine and $\omega-3$ polyunsaturated fatty acids. J. Parenter. Enter. Nutr. 2016, 40, 52-66. [CrossRef] [PubMed]

82. Wang, Z.Q.; Chen, M.T.; Zhang, R.; Zhang, Y.; Li, W.; Li, Y.G. Docosahexaenoic acid attenuates doxorubicin-induced cytotoxicity and inflammation by suppressing NF- $\mathrm{kB} / \mathrm{iNOS} / \mathrm{NO}$ signaling pathway activation in H9C2 cardiac cells. J. Cardiovasc. Pharmacol. 2016, 67, 283-289. [CrossRef] [PubMed]

83. Vishnu, K.V.; Ajeesh Kumar, K.K.; Chatterjee, N.S.; Lekshmi, R.G.K.; Sreerekha, P.R.; Mathew, S.; Ravishankar, C.N. Sardine oil loaded vanillic acid grafted chitosan microparticles, a new functional food ingredient: Attenuates myocardial oxidative stress and apoptosis in cardiomyoblast cell lines (H9c2). Cell Stress Chaperones 2017. [CrossRef] [PubMed] 
84. Edwardson, D.W.; Narendrula, R.; Chewchuk, S.; Mispel-Beyer, K.; Mapletoft, J.P.; Parissenti, A.M. Role of drug metabolism in the cytotoxicity and clinical efficacy of anthracyclines. Curr. Drug Metab. 2015, 16, 412-426. [CrossRef] [PubMed]

85. Arcamone, F.M. From the pigments of the actinomycetes to third generation antitumor anthracyclines. Biochimie 1998, 80, 201-206. [CrossRef]

86. Preobrazhenskaya, M.N.; Tevyashova, A.N.; Olsufyeva, E.N.; Huang, H.-F.; Huang, H.S. Second generation drugs-Derivatives of natural anti-tumor anthracycline antibiotics Daunorubicin, Doxorubicin and Carminomycin. J. Med. Sci. 2006, 26, 119-128.

87. Cortes-Funes, H.; Coronado, C. Role of anthracyclines in the era of targeted therapy. Cardiovasc. Toxicol. 2007, 7, 56-60. [CrossRef] [PubMed]

88. Fumoleau, P.; Roche, H.; Kerbrat, P.; Bonneterre, J.; Romestaing, P.; Fargeot, P.; Namer, M.; Monnier, A.; Montcuquet, P.; Goudier, M.J.; et al. Long-term cardiac toxicity after adjuvant epirubicin-based chemotherapy in early breast cancer: French Adjuvant Study Group results. Ann. Oncol. 2006, 17, 85-92. [CrossRef] [PubMed]

89. Chien, A.J.; Moasser, M.M. Cellular mechanisms of resistance to anthracyclines and taxanes in cancer: Intrinsic and acquired. Semin. Oncol. 2008, 35, S1-S14. [CrossRef] [PubMed]

90. Bartlett, J.J.; Trivedi, P.C.; Pulinilkunnil, T. Autophagic dysregulation in doxorubicin cardiomyopathy. J. Mol. Cell. Cardiol. 2017, 104, 1-8. [CrossRef] [PubMed]

91. Gammella, E.; Maccarinelli, F.; Buratti, P.; Recalcati, S.; Cairo, G. The role of iron in anthracycline cardiotoxicity. Front. Pharmacol. 2014, 5, 25. [CrossRef] [PubMed]

92. Vejpongsa, P.; Yeh, E.T. Prevention of anthracycline-induced cardiotoxicity: Challenges and opportunities. J. Am. Coll. Cardiol. 2014, 64, 938-945. [CrossRef] [PubMed]

93. Ichikawa, Y.; Ghanefar, M.; Bayeva, M.; Wu, R.; Khechaduri, A.; Naga Prasad, S.V.; Mutharasan, R.K.; Naik, T.J.; Ardehali, H. Cardiotoxicity of doxorubicin is mediated through mitochondrial iron accumulation. J. Clin. Investig. 2014, 124, 617-630. [CrossRef] [PubMed]

94. Link, G.; Tirosh, R.; Pinson, A.; Hershko, C. Role of iron in the potentiation of anthracycline cardiotoxicity: Identification of heart cell mitochondria as a major site of iron-anthracycline interaction. J. Lab. Clin. Med. 1996, 127, 272-278. [CrossRef]

95. Van Dalen, E.C.; Caron, H.N.; Dickinson, H.O.; Kremer, L.C. Cardioprotective interventions for cancer patients receiving anthracyclines. Cochrane Database Syst. Rev. 2011, 6, CD003917.

96. Dresdale, A.R.; Barr, L.H.; Bonow, R.O.; Mathisen, D.J.; Myers, C.E.; Schwartz, D.E.; D'Angelo, T.; Rosenberg, S.A. Prospective randomized study of the role of $N$-acetyl cysteine in reversing doxorubicin-induced cardiomyopathy. Am. J. Clin. Oncol. 1982, 5, 657-663. [CrossRef] [PubMed]

97. Panjrath, G.S.; Patel, V.; Valdiviezo, C.I.; Narula, N.; Narula, J.; Jain, D. Potentiation of Doxorubicin cardiotoxicity by iron loading in a rodent model. J. Am. Coll. Cardiol. 2007, 49, 2457-2464. [CrossRef] [PubMed]

98. Hasinoff, B.B.; Schnabl, K.L.; Marusak, R.A.; Patel, D.; Huebner, E. Dexrazoxane (ICRF-187) protects cardiac myocytes against doxorubicin by preventing damage to mitochondria. Cardiovasc. Toxicol. 2003, 3, 89-99. [CrossRef] [PubMed]

99. Martin, E.; Thougaard, A.V.; Grauslund, M.; Jensen, P.B.; Bjorkling, F.; Hasinoff, B.B.; Tjørnelund, J.; Sehested, M.; Jensen, L.H. Evaluation of the topoisomerase II-inactive bisdioxopiperazine ICRF-161 as a protectant against doxorubicin-induced cardiomyopathy. Toxicology 2009, 255, 72-79. [CrossRef] [PubMed]

100. Nitiss, K.C.; Nitiss, J.L. Twisting and ironing: Doxorubicin cardiotoxicity by mitochondrial DNA damage. Clin. Cancer Res. 2014, 20, 4737-4739. [CrossRef] [PubMed]

101. Zhang, S.; Liu, X.; Bawa-Khalfe, T.; Lu, L.S.; Lyu, Y.L.; Liu, L.F.; Yeh, E.T. Identification of the molecular basis of doxorubicin-induced cardiotoxicity. Nat. Med. 2012, 18, 1639-1642. [CrossRef] [PubMed]

102. Abd El-Aziz, T.A.; Mohamed, R.H.; Pasha, H.F.; Abdel-Aziz, H.R. Catechin protects against oxidative stress and inflammatory-mediated cardiotoxicity in adriamycin-treated rats. Clin. Exp. Med. 2012, 12, 233-240. [CrossRef] [PubMed]

103. Guo, R.; Lin, J.; Xu, W.; Shen, N.; Mo, L.; Zhang, C.; Feng, J. Hydrogen sulfide attenuates doxorubicin-induced cardiotoxicity by inhibition of the p38 MAPK pathway in H9c2 cells. Int. J. Mol. Med. 2013, 31, 644-650. [CrossRef] [PubMed] 
104. Pecoraro, M.; Del Pizzo, M.; Marzocco, S.; Sorrentino, R.; Ciccarelli, M.; Iaccarino, G.; Pinto, A.; Popolo, A. Inflammatory mediators in a short-time mouse model of doxorubicin-induced cardiotoxicity. Toxicol. Appl. Pharmacol. 2016, 293, 44-52. [CrossRef] [PubMed]

105. Holmgren, G.; Synnergren, J.; Andersson, C.X.; Lindahl, A.; Sartipy, P. MicroRNAs as potential biomarkers for doxorubicin-induced cardiotoxicity. Toxicol. In Vitro 2016, 34, 26-34. [CrossRef] [PubMed]

106. Saddic, L.A.; Muehlschlegel, J.D. Sarco "MiR" friend or foe: A perspective on the mechanisms of doxorubicin-induced cardiomyopathy. Ann. Transl. Med. 2016, 4, 203. [CrossRef] [PubMed]

107. Fasano, E.; Serini, S.; Piccioni, E.; Toesca, A.; Monego, G.; Cittadini, A.R.; Ranelletti, F.O.; Calviello, G. DHA induces apoptosis by altering the expression and cellular location of GRP78 in colon cancer cell lines. Biochim. Biophys. Acta 2012, 1822, 1762-1772. [CrossRef] [PubMed]

108. Dirks-Naylor, A.J.; Kouzi, S.A.; Yang, S.; Tran, N.T.; Bero, J.D.; Mabolo, R.; Phan, D.T.; Whitt, S.D.; Taylor, H.N. Can short-term fasting protect against doxorubicin-induced cardiotoxicity? World J. Biol. Chem. 2014, 5, 269-274. [CrossRef] [PubMed]

109. Pizarro, M.; Troncoso, R.; Martinez, G.J.; Chiong, M.; Castro, P.F.; Lavandero, S. Basal autophagy protects cardiomyocytes from doxorubicin-induced toxicity. Toxicology 2016, 370, 41-48. [CrossRef] [PubMed]

110. Loos, B.; du Toit, A.; Hofmeyr, J.H. Defining and measuring autophagosome flux-concept and reality. Autophagy 2014, 10, 2087-2096. [CrossRef] [PubMed]

111. Cappetta, D.; Rossi, F.; Piegari, E.; Quaini, F.; Berrino, L.; Urbanek, K.; De Angelis, A. Doxorubicin targets multiple players: A new view of an old problem. Pharmacol. Res. 2017. [CrossRef] [PubMed]

112. Matsui, H.; Morishima, I.; Hayashi, K.; Kamiya, H.; Saburi, Y.; Okumura, K. Dietary fish oil does not prevent doxorubicin-induced cardiomyopathy in rats. Can. J. Cardiol. 2002, 18, 279-286. [PubMed]

113. Carbone, A.; Psaltis, P.J.; Nelson, A.J.; Metcalf, R.; Richardson, J.D.; Weightman, M.; Thomas, A.; Finnie, J.W.; Young, G.D.; Worthley, S.G. Dietary $\omega-3$ supplementation exacerbates left ventricular dysfunction in an ovine model of anthracycline-induced cardiotoxicity. J. Card. Fail. 2012, 18, 502-511. [CrossRef] [PubMed]

114. Germain, E.; Lavandier, F.; Chajès, V.; Schubnel, V.; Bonnet, P.; Lhuillery, C.; Bougnoux, P. Dietary n-3 polyunsaturated fatty acids and oxidants increase rat mammary tumor sensitivity to epirubicin without change in cardiac toxicity. Lipids 1999, 34, S203. [CrossRef] [PubMed]

115. Germain, E.; Bonnet, P.; Aubourg, L.; Grangeponte, M.C.; Chajès, V.; Bougnoux, P. Anthracycline-induced cardiac toxicity is not increased by dietary $\omega-3$ fatty acids. Pharmacol. Res. 2003, 47, 111-117. [CrossRef]

116. Schjøtt, J.; Brurok, H.; Jynge, P.; Bjerve, K.S. Effects of eicosapentaenoic acid and docosahexaenoic acid diet supplement on tolerance to the cardiotoxicity of epirubicin and to ischaemia reperfusion in the isolated rat heart. Pharmacol. Toxicol. 1996, 79, 65-72. [CrossRef] [PubMed]

117. Yu, X.; Cui, L.; Zhang, Z.; Zhao, Q.; Li, S. $\alpha$-Linolenic acid attenuates doxorubicin-induced cardiotoxicity in rats through suppression of oxidative stress and apoptosis. Acta Biochim. Biophys. Sin. 2013, 45, 817-826. [CrossRef] [PubMed]

118. Hajjaji, N.; Besson, P.; Bougnoux, P. Tumor and non-tumor tissues differential oxidative stress response to supplemental DHA and chemotherapy in rats. Cancer Chemother. Pharmacol. 2012, 70, 17-23. [CrossRef] [PubMed]

119. Vitelli, M.R.; Filippelli, A.; Rinaldi, B.; Rossi, S.; Palazzo, E.; Rossi, F.; Berrino, L. Effects of docosahexaenoic acid on $\left[\mathrm{Ca}^{2+}\right]_{i}$ increase induced by doxorubicin in ventricular rat cardiomyocytes. Life Sci. 2002, 71, 1905-1916. [CrossRef]

120. Lau, D.H.; Psaltis, P.J.; Carbone, A.; Kelly, D.J.; Mackenzie, L.; Worthington, M.; Metcalf, R.G.; Kuklik, P.; Nelson, A.J.; Zhang, Y.; et al. Atrial protective effects of $n-3$ polyunsaturated fatty acids: A long-term study in ovine chronic heart failure. Heart Rhythm 2011, 8, 575-582. [CrossRef] [PubMed]

121. Fasano, E.; Serini, S.; Cittadini, A.; Calviello, G. Long-chain n-3 PUFA against breast and prostate cancer: Which are the appropriate doses for intervention studies in animals and humans? Crit. Rev. Food Sci. Nutr. 2017, 57, 2245-2262. [CrossRef] [PubMed]

122. Menna, P.; Salvatorelli, E. Primary prevention strategies for anthracycline cardiotoxicity: A brief overview. Chemotherapy 2017, 62, 159-168. [CrossRef] [PubMed]

123. Brenna, J.T. Efficiency of conversion of $\alpha$-linolenic acid to long chain $n$ - 3 fatty acids in man. Curr. Opin. Clin. Nutr. Metab. Care 2002, 5, 127-132. [CrossRef] [PubMed] 
124. Colas, S.; Mahéo, K.; Denis, F.; Goupille, C.; Hoinard, C.; Champeroux, P.; Tranquart, F.; Bougnoux, P. Sensitization by dietary docosahexaenoic acid of rat mammary carcinoma to anthracycline: A role for tumor vascularization. Clin. Cancer Res. 2006, 12, 5879-5886. [CrossRef] [PubMed]

125. Serini, S.; Fasano, E.; Piccioni, E.; Cittadini, A.R.; Calviello, G. Dietary $n-3$ polyunsaturated fatty acids and the paradox of their health benefits and potential harmful effects. Chem. Res. Toxicol. 2011, 24, 2093-2105. [CrossRef] [PubMed]

126. Cetrullo, S.; Tantini, B.; Flamigni, F.; Pazzini, C.; Facchini, A.; Stefanelli, C.; Caldarera, C.M.; Pignatti, C. Antiapoptotic and antiautophagic effects of eicosapentaenoic acid in cardiac myoblasts exposed to palmitic acid. Nutrients 2012, 4, 78-90. [CrossRef] [PubMed]

127. Hsu, H.C.; Chen, C.Y.; Chiang, C.H.; Chen, M.F. Eicosapentaenoic acid attenuated oxidative stress-induced cardiomyoblast apoptosis by activating adaptive autophagy. Eur. J. Nutr. 2014, 53, 541-547. [CrossRef] [PubMed]

128. Gwon, D.H.; Hwang, T.W.; Ro, J.Y.; Kang, Y.J.; Jeong, J.Y.; Kim, D.K.; Lim, K.; Kim, D.W.; Choi, D.E.; Kim, J.J. High endogenous accumulation of $\omega-3$ polyunsaturated fatty acids protect against ischemia-reperfusion renal injury through AMPK-mediated autophagy in Fat-1 mice. Int. J. Mol. Sci. 2017, 18, 2081. [CrossRef] [PubMed]

129. Pettersen, K.; Monsen, V.T.; Hakvåg Pettersen, C.H.; Overland, H.B.; Pettersen, G.; Samdal, H.; Tesfahun, A.N.; Lundemo, A.G.; Bjørkøy, G.; Schønberg, S.A. DHA-induced stress response in human colon cancer cells-Focus on oxidative stress and autophagy. Free Radic. Biol. Med. 2016, 90, 158-172. [CrossRef] [PubMed]

130. Karimi, M.; Vedin, I.; Freund Levi, Y.; Basun, H.; Faxén Irving, G.; Eriksdotter, M.; Wahlund, L.O.; Schultzberg, M.; Hjorth, E.; Cederholm, T.; et al. DHA-rich n-3 fatty acid supplementation decreases DNA methylation in blood leukocytes: The $\Omega$ D study. Am. J. Clin. Nutr. 2017, 106, 1157-1165. [CrossRef] [PubMed]

131. Valenzuela, R.; Rincón-Cervera, M.Á.; Echeverría, F.; Barrera, C.; Espinosa, A.; Hernández-Rodas, M.C.; Ortiz, M.; Valenzuela, A.; Videla, L.A. Iron-induced pro-oxidant and pro-lipogenic responses in relation to impaired synthesis and accretion of long-chain polyunsaturated fatty acids in rat hepatic and extrahepatic tissues. Nutrition 2018, 45, 49-58. [CrossRef] [PubMed] 